\title{
Intense Precipitation and Area of Risk: A Case Study of Mass Movement in the City of Natal, Brazil
}

\author{
Marcos Samuel Matias Ribeiro ${ }^{1, *}$, Maria Helena Constantino Spyrides ${ }^{2}$, Lara de Melo Barbosa Andrade ${ }^{2}$, \\ Kellen Carla Lima ${ }^{2}$, Venerando Eustáquio Amaro ${ }^{3}$, Lívian Rafaely de Santana Gomes Pinheiro ${ }^{4}$ (D), \\ Maytê Duarte Leal Coutinho ${ }^{5}$ and Juliana Emanuelle da Costa Andrade Alves 6
}

check for

updates

Citation: Ribeiro, M.S.M.; Spyrides, M.H.C.; Andrade, L.d.M.B.; Lima,

K.C.; Amaro, V.E.; Pinheiro,

L.R.d.S.G.; Coutinho, M.D.L.; Alves, J.E.d.C.A. Intense Precipitation and Area of Risk: A Case Study of Mass Movement in the City of Natal, Brazil Water 2021, 13, 3346. https:// doi.org/10.3390/w13233346

Academic Editor: Scott Curtis

Received: 7 October 2021

Accepted: 3 November 2021

Published: 25 November 2021

Publisher's Note: MDPI stays neutral with regard to jurisdictional claims in published maps and institutional affiliations.

Copyright: (c) 2021 by the authors. Licensee MDPI, Basel, Switzerland. This article is an open access article distributed under the terms and conditions of the Creative Commons Attribution (CC BY) license (https:// creativecommons.org/licenses/by/ $4.0 /)$.
1 Campus Paragominas, Federal Rural University of the Amazon (UFRA), Paragominas 68625-970, PA, Brazil

2 Graduate Program in Climate Sciences, Federal University of Rio Grande do Norte (UFRN), Natal 59078-970, RN, Brazil; mhspyrides@gmail.com (M.H.C.S.); lara.ufrn@gmail.com (L.d.M.B.A.); kellencarla@gmail.com (K.C.L.)

3 Graduate Program in Civil Engineering, Federal University of Rio Grande do Norte (UFRN), Natal 59078-970, RN, Brazil; venerando.amaro@gmail.com

4 Graduate Program in Development and Environment, Federal University of Rio Grande do Norte, Natal 59078-970, RN, Brazil; livianrafaely@gmail.com

5 Third District of Meteorology, Recife 50020-150, PE, Brazil; maytecoutinho@yahoo.com.br

6 Graduate Program in Aerospace Engineering, Federal University of Rio Grande do Norte, Natal 59078-970, RN, Brazil; juliana.emanuelle@outlook.com

* Correspondence: msamuel19@outlook.com

\begin{abstract}
This study aims to analyze the atmospheric conditions associated with an event of intense precipitation caused by Easterly Wave Disturbances (EWDs), as well as the environmental conditions related to the mass gravitational movement that occurred between 14th June and 15th June of 2014, in the district of Mãe Luiza, Natal/RN/Brazil. The synoptic conditions, the vertical integrated moisture flux and the energetic behavior in the EWD's performance phases were analyzed. In addition to these factors, local environmental aspects were assessed, classifying the vulnerability to disaster events in the affected area. Over the days of the operation of the atmospheric system, the daily accumulation of precipitation was greater than $100 \mathrm{~mm}$, with precipitation accumulated in $3 \mathrm{~h}$ in the order of $60 \mathrm{~mm}$ for the stages of maturation of the disturbance. The main synoptic conditions associated with EWDs were exhibited by the intense anomalies of wind speed and high humidity flux on the east coast of the Northeast, which intensified the influx of moisture into the continent over the period of the operation of the system. Conditions of high to very high vulnerability were identified in the area where the event took place and also in other expressive parts of the district.
\end{abstract}

Keywords: easterly wave disturbances; debris flow; physical environment; vulnerability

\section{Introduction}

The occurrence of extreme precipitation events maximizes episodes of natural disasters, such as floods, torrents and gravitational mass movements. These disaster situations simultaneously involve social and natural processes that impact society [1-3], with anthropogenic actions being one of the deterministic factors, combined with weather conditions, therefore requiring attention from the civil defense and other governmental authorities [4].

The environmental changes made over the years, caused by the process of urbanization and industrialization, have led to changes in weather patterns, making extreme precipitation events increasingly frequent [5]. According to the Intergovernmental Panel on Climate Change, an increase of $1.5^{\circ} \mathrm{C}$ in global temperature is estimated by 2100 [6], which could cause an increase in the frequency and intensity of extreme events. In Northeast Brazil, rainfall is estimated at around $178 \mathrm{~mm}$ during June, July and August, with a two-year return period [7]. 
In the Brazilian state of Rio Grande do Norte, from 13th to 15th June 2014, intense rainfall occurred, with accumulations greater than $100 \mathrm{~mm}$ daily, a period in which the state capital, Natal, hosted matches of the World Cup. Studies showed that an Easterly Wave Disturbance (EWD) was the main atmospheric system responsible for the high rainfall in the region [8,9]. The city's civil defense agency has reported that $40 \mathrm{~mm}$ of rainfall in the city is enough to cause local disturbances, as well as to increase the occurrence of natural disasters. Therefore, the occurrence of mass movement was aggravated in some of the hillsides to the east of the district of Mãe de Luiza, located in the eastern part of Natal. This affected 187 families, 26 of which had their houses totally destroyed.

There were (and still are) socio-environmental conflicts in the district of Mãe Luiza, since it was established as a Special Zone of Social Interest (ZEIS) by State Law 4663/95, included in the urban zoning in Natal's Master Plan as an urban occupation area on a fragment of the dune field that constitutes Environmental Protection Zone 10, the dune slopes of Mãe Luiza Lighthouse, and the Environmental Protection Zone 2, known as Dunas State Park of Natal [10]. The urban arrangement of Mãe Luiza ZEIS has typical characteristics of informal urban land use and occupation, which pose threats both to the resident population and to the natural elements of the environment, in this case dune fields with high environmental fragility, previously covered by Atlantic Forest vegetation and sandbanks [11].

In recent years, the damage caused by weather events has been intensifying, often linked to the lack of urban planning. With the process of urban growth, many areas have been occupied that are unsuitable for anthropic use. Among these locations are hillside and mountain areas, without any adjustments being made to mitigate and/or adapt to the natural fragilities of the land or to reduce the exposure of the people in such communities. This threat is magnified by the socioeconomic vulnerability of these communities. Such characteristics of the anthropization process increase the exposure of the people that occupy these urban spaces and thus also increase the likelihood of disasters.

The rapid growth of urban centers without proper planning has impelled the population to occupy areas more exposed to the occurrence of natural disasters, especially the most vulnerable people with low economic power [12]. The occupation of areas susceptible to intense natural phenomena, such as hillsides and coastal zones, amplifies the probability of harmful events, such as mass movements, which cause loss of property and human lives.

The occurrence of mass movements involves different factors that are directly or indirectly associated, starting with aspects of the physical environment, such as: the complexions of geological and structural features (texture of the material, presence of fractures, faults and other discontinuities); geotechnical and hydrological properties of materials, such as granulometry, cohesion, porosity, permeability, shear strength and conductivity; morphometric and morphological attributes of the terrain, such as slope, aspect and hill shape; and socioeconomic aspects of land use and coverage, especially in occupied deforested areas, often prone to greater and faster soil saturation during intense precipitation. In most cases, rain is one of the main triggers of mass movements [13,14].

Therefore, this study analyzes the atmospheric conditions associated with an event of intense precipitation caused by an Easterly Wave Disturbance (EWD), as well as the environmental conditions related to the mass movement that occurred on 14-15 June 2014, in the district of Mãe Luiza, Natal, Rio Grande do Norte. The understanding of the different factors involved in this intense rainfall event will contribute to elucidating the disaster, providing support for the planning and application of effective public policies to reduce and mitigate risks in the district.

\section{Materials and Methods}

\subsection{Study Area}

The Mãe Luiza district, situated on the east side of the city of Natal (Latitude: $5^{\circ} 47^{\prime} 57.70^{\prime \prime}$ S Longitude: $35^{\circ} 10^{\prime} 59.66^{\prime \prime}$ O), capital of Rio Grande do Norte (Figure 1), has a population of 14,959, distributed in 4390 households, according to the Brazilian Insti- 
tute of Geography and Statistics [15]. It covers approximately 95.7 hectares and occupies a portion of a previously vegetated dune field, with accentuated erosion by the action of water due to the high waterproofing of the soil promoted by urbanization, with houses built on sandy soil, accompanied by deficient rain drainage and sanitary sewage systems with poor maintenance.

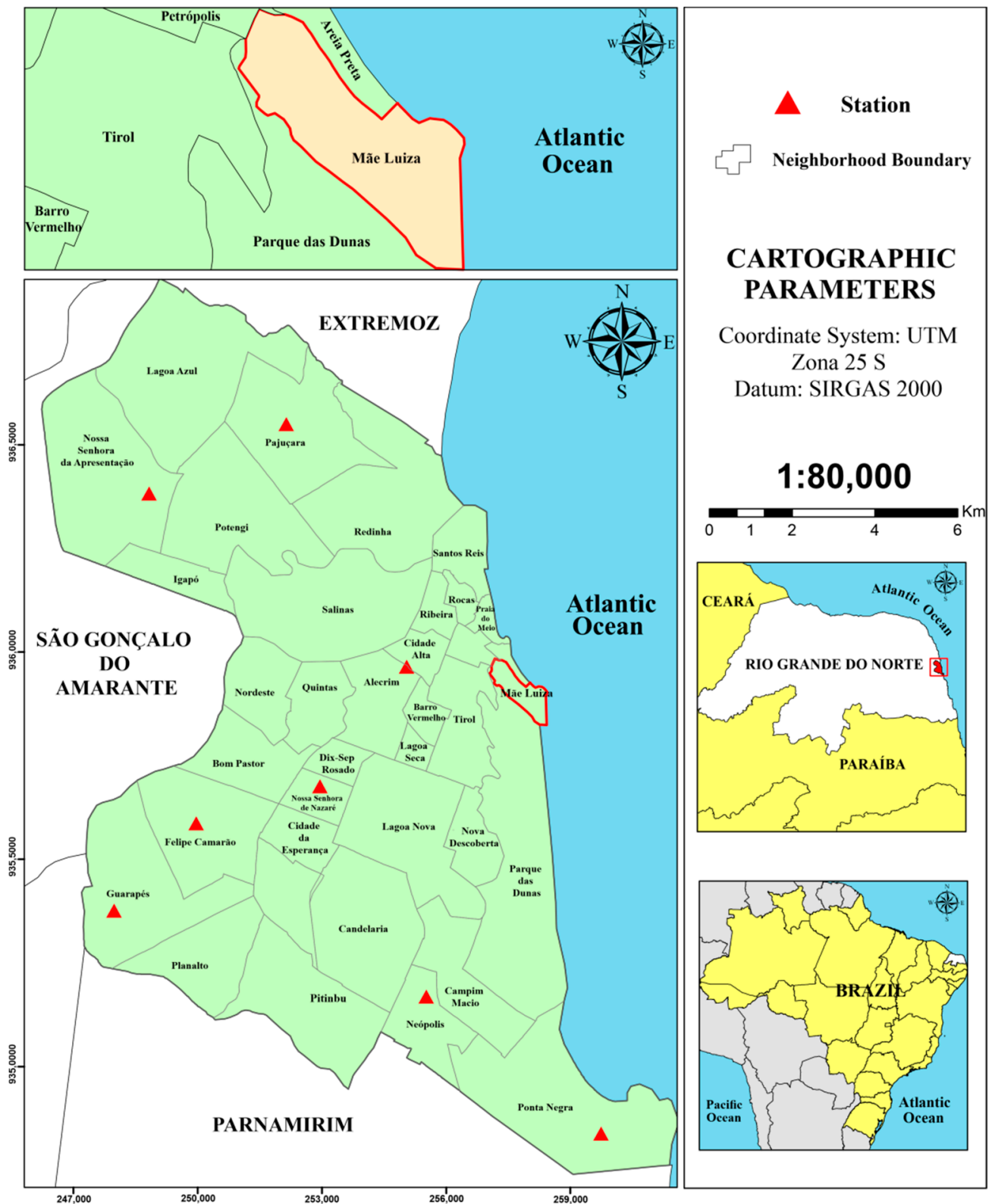

Figure 1. Location of the district of Mãe Luiza, situated in the Eastern Zone of Natal.

The precipitation regime for the region, in addition to being related to its proximity to the ocean, is influenced by atmospheric systems, among which Easterly Wave Disturbances (EWDs) stand out. These systems are responsible for high amounts of rainfall along the coast the Northeast region of Brazil. These are atmospheric disturbances observed in the tropics, in the area of influence of the trade winds, moving from east to west, that is, in the Southern Hemisphere, from the west coast of Africa to the east coast of Brazil, which are associated with low pressure and high sea surface temperatures [16]. EWDs are extremely important because they cause significant changes in atmospheric conditions, mainly in the southern wind component, resulting in the humidification of the atmospheric layer, 
increased cloudiness and precipitation [17]. These atmospheric systems vary in size and intensity depending on the time of year and the region of the globe [18].

Researchers studying the occurrence of an EWD in the state of Rio Grande do Norte (Northeast Brazil) observed that the atmospheric system occurred close to the Brazilian northeast coast as an extension of the convective activity present in the Intertropical Convergence Zone (ITCZ) [8]. The increase in the intensity of the system was related to the higher sea surface temperature in the Atlantic adjacent to the northeast coast, where the system strengthened when approaching the continental shelf, where the water is shallower.

\subsection{Data}

To assess the event of intense precipitation that occurred in Natal between 12th and 15th June, 2014, satellite images from GOES 13 and Meteosat 10 were initially used, provided by the Satellite and Environmental Systems Division of the Center for Weather Forecasting and Climate Studies of the National Institute for Space Research (DSA/CPTEC/INPE). These images were used to ascertain the life cycle of the atmospheric system, thus defining its phases: formation (0600 UTC/12th June); maturation (1600 UTC/13th June); and dissipation (0930 UTC/14th June). In addition, the EWD had a second stage, consisting of reintensification (1200 UTC/14th June), maturation 2 (0000 UTC/15th June) and dissipation 2 (1800 UTC/15th June).

In the analysis of the pluviometric volume, daily precipitation data provided by the National Center for Monitoring Natural Disaster Alerts (CEMADEN) were used. These data are collected through a network of rain gauges containing eight instruments, distributed in the districts of Natal in its four zones (North, South, East and West). Because the precipitation was not simultaneous with the satellite images' transmission, the data were organized in accumulated hours and aggregated in a period of three hours. Thus, we used the hour before and after the steps involving the atmospheric system in question.

The data for the meridional and zonal components of the wind, air temperature, relative vorticity, divergence, specific humidity and vertical speed were obtained from ERA5 reanalysis (fifth generation of atmospheric reanalysis) of the European Centre for MediumRange Weather Forecasts (ECMWF), developed by the Copernicus Climate Change Service (CS3), with hourly analysis fields and horizontal resolution of $0.3^{\circ}$ latitude $\times 0.3^{\circ}$ longitude, 139 pressure levels, from the surface to $0.01 \mathrm{hPa}$ (about $80 \mathrm{~km}$ ). These data were used to analyze the synoptic environment in which the atmospheric system was inserted, in addition to the flux of humidity and energy variations during the period of the EWD.

The spatial data used to assess physical vulnerability were obtained from the repositories of Natal's Department of Urban Mobility (SEMURB), the Applied Geotechnology, Coastal and Oceanic Modeling Laboratory (GNOMO/UFRN) and also the Basic Sanitation Services Regulatory Agency of the City of Natal (ARSBAN). Such spatial data are georeferenced and based on geodetic surveys with high precision and accuracy, including the derivation of the Digital Terrain Model (DTM) and the Digital Surface Model (DSM), and integrated in a Geographic Information System (GIS) for the analysis of environmental vulnerability to mass movements (Table 1). 
Table 1. Spatial layers used in the calculation of environmental vulnerability of landslides in the district of Mãe Luiza, Natal, RN.

\begin{tabular}{|c|c|c|c|}
\hline Base Map & Source & Product & Scale * \\
\hline Districts & Semurb & Vector product (shapefile). & 1:850 \\
\hline Orthomosaic & Semurb & $\begin{array}{l}\text { Raster product, obtained from the } \\
\text { orthorectification of Google Earth } \\
\text { images in 2012-2013 and } 2016 \\
\text { (resolution of } 0.17 \mathrm{~m})\end{array}$ & $1: 850$ \\
\hline Original DTM & GNOMO & $\begin{array}{c}\text { TIN interpolation of contour lines } \\
\text { of } 1 \text { m equidistant from } \\
\text { Semurb (2006) }\end{array}$ & $1: 2500$ \\
\hline Calibrated DTM & GNOMO & $\begin{array}{l}\text { Geodesically calibrated according } \\
\text { to the MAPGEO2015 reference } \\
\text { surface system (resolution } 0.5 \mathrm{~m} \text { ). }\end{array}$ & $1: 2500$ \\
\hline DSM & GNOMO & $\begin{array}{c}\text { Derived from calibrated DTM: } \\
\text { addition of } 5 \mathrm{~m} \text { for buildings and } \\
0.2 \mathrm{~m} \text { for sidewalks (resolution } \\
\text { of } 0.5 \mathrm{~m} \text { ) }\end{array}$ & $1: 2500$ \\
\hline Environmental Data & Source & Processing/Product & Scale * \\
\hline Declivity & GNOMO & $\begin{array}{l}\text { Derived from DSM in degrees } \\
\quad \text { (resolution } 0.5 \mathrm{~m} \text { ) }\end{array}$ & $1: 2500$ \\
\hline Vegetation & GNOMO & $\begin{array}{l}\text { Vector data mapped by screen } \\
\text { capture, stemming from Semurb's } \\
2016 \text { Orthomosaic }\end{array}$ & 1:1000 \\
\hline Use and coverage & GNOMO & $\begin{array}{l}\text { Vector data mapped by screen } \\
\text { capture, from Semurb's } \\
2016 \text { Orthomosaic }\end{array}$ & $1: 1000$ \\
\hline Geomorphology & GNOMO & $\begin{array}{l}\text { Vector data mapped by screen } \\
\text { capture, from Semurb's } \\
2016 \text { Orthomosaic }\end{array}$ & $1: 1000$ \\
\hline $\begin{array}{l}\text { Average Defluvium } \\
\text { Coefficient } \\
\text { (C)-Drainage Master } \\
\text { Plan (DMP) of Natal }\end{array}$ & ARSBAN & $\begin{array}{l}\text { Vector data provided in shapefiles } \\
\text { for } 2008 \text { and projected for } 2028 \text {. It } \\
\text { measures surface runoff, defined } \\
\text { by the ratio between the volume of } \\
\text { water runoff and the volume of } \\
\text { precipitated water. } \\
\text { C = Lost_Volume/Precipitated_Vol. }\end{array}$ & $1: 5000$ \\
\hline PedologY (DMP) & ARSBAN & Vector data provided in shapefiles & $1: 5000$ \\
\hline Geology & ARSBAN & Vector data provided in shapefiles & $1: 5000$ \\
\hline
\end{tabular}

${ }^{*}$ Data Matrix (Raster) $->$ Scale = 1: (Resolution/0.0002).

\subsection{Methodology}

\subsubsection{Water Vapor Transport}

The balance of moisture convergence during the occurrence of the EWD was calculated over a rectangular area delimited between $-8.7^{\circ}$ and $-10.4^{\circ} ;-35^{\circ}$ and $-38.2^{\circ}$, which encompasses the state of Rio Grande do Norte. The area considered to study the transport of water vapor, in and out of it, includes the city of Natal, the most affected by the EWD. The vertical integration of moisture fluxes was carried out using the methodology of [19], since this formulation has been used successfully in other studies [20-23]. It is based on the following equations:

$$
Q_{v}=\frac{1}{g} \int_{p_{t}}^{\rho_{\sigma}} q v d p
$$




$$
Q_{u}=\frac{1}{g} \int_{p_{t}}^{\rho_{\sigma}} q u d p
$$

where: $Q_{v}$ and $Q_{u}$ represent the meridional and zonal moisture flux, respectively; $g$ is acceleration due to gravity; $q$ is the specific humidity; $u$ and $v$ are the components of the southern and zonal wind, respectively; pt denotes the pressure at the top of the integration domain $(300 \mathrm{hPa})$; and $p 0$ is the pressure at the surface $(\mathrm{hPa})$. The unit of these fluxes is $\mathrm{kg} / \mathrm{s}$.

The moisture fluxes along the eastern and western borders were calculated as follows:

$$
\begin{aligned}
& Q_{E W}=\int_{\text {lat } 1}^{\text {lat } 0} Q_{i} d y \\
& Q_{N S}=\int_{\text {lon } 1}^{l o n 0} Q_{i} d x
\end{aligned}
$$

The integration was carried out by setting the latitude or longitude between the limits of the borders of each area, according to the indices previously defined in the equations, where: the EW indices of Equation (3) define the longitude to set the eastern or western borders; the integration is performed in the $y$ direction; $\phi 1$ is the value of latitude on the southern edge; and $\$ 2$ is the value of latitude on the northern edge. The NS index of Equation (4) defined the latitude to set the northern or southern boundaries. In this case, the integration was performed in the $x$ direction, where $\lambda 1$ is the longitude value on the western edge and $\lambda 2$ is the longitude value on the eastern edge. The $i$ index in both equations defines the meridional, zonal or total moisture flux, already vertically integrated.

The balance of signs for calculating the convergence was determined according to the boundaries of the defined areas. For the northern and eastern edges, if the value is negative, there is an entry or gain in flux, which must be added to the total balance; if the value is positive, there is an outflow or loss of flux, which must be subtracted. On the southern and western edges, the opposite occurs: if the value is positive, there is an entry or gain of flux, so it must be added; if the value is negative, there is an outflow or loss of flux, so the total convergence balance must be subtracted.

\subsubsection{Energy Analysis}

In order to study the availability of energy in the atmosphere, seeking its influence during the period of the atmospheric system, Lorenz energy was used. This seeks to identify the generation and conversion of energy through a diagram with four boxes [24], which represents the storage of the different types of energy involved in the system, in addition to the direction of the flux represented by the arrows, which suggest the presence of sources, sinks or terms of conversion [25].

As described in previous studies, the submerged energies are classified into elements of the basic state and disturbance, as follows: potential available energy of the basic state (AZ); potential available energy of the disturbance (AE); kinetic energy of the basic state (KZ); and disturbance (KE). Thus, the conversions analyzed between the forms of energy are AZ-AE (CA), AE-KE (KE), KE-KZ (CK) and AZ-KZ (CZ). The CA and CE conversions correspond to the baroclinic instability cycle, and $\mathrm{CK}$ and $\mathrm{CZ}$ to the barotropic cycle. These fluxes are calculated through horizontal integration of the limit area and the vertical integration between the levels of 1000 and $100 \mathrm{hPa}[21,26]$.

\subsubsection{Analysis of Environmental Vulnerability}

With the environmental conditions of the hillside where Mãe Luiza is located, a possible area of environmental preservation with a closed forest, we sought to assess the predisposition of the area to mass movements. Initially, the DTM was generated by triangular irregular network (TIN) interpolation of contour lines equidistant at $1 \mathrm{~m}$, derived from orthophotomosaics provided by the Natal Department of Urban Mobility (SEMURB) 
from an altimetric survey carried out in 2006, based on the processing available in the Arc Map 10.3○ computational suite. The planialtimetric calibration was based on 14 geodetic control points distributed in the area of interest by the team of the Laboratory of Applied Geotechnologies, Coastal and Marine Ocean Modeling (GNOMO) of Federal University of Rio Grande do Norte, on 29 November 2018, according to the method suggested by Lima and collaborators [27].

Calibration of the DTM was performed in the QGIS 3.4.12GNU suite with linear regression adjustment, with the aid of the bootstrap simulation method, which uses resampling in the original database to obtain a new dataset, possibly containing a greater number of elements. Thus, the expression $y=1.513+1.015 x$ was obtained, where y is geodesically calibrated altimetry and $x$ is aerial lift altimetry.

For the development of the DSM, the following strategies were established: (i) the various classes of dunes, the coastline and the level of the pavement of the access roads received differential altimetry of $0.0 \mathrm{~m}$, as they correspond to the calibrated base DTM; (ii) the urban lots received a value of $5.0 \mathrm{~m}$, considering that most of the buildings have one floor; and (iii) the mapped sidewalks received a value of $0.2 \mathrm{~m}$. The use and coverage map used as a base was made from the high-resolution orthomosaics available in the Google Earth repository (2012-2013 and 2016), orthorectified for integration in the SEMURB database. The vector file for land use and coverage was transformed into a raster based on the assigned altimetry values and integrated into algebraic operations with the calibrated DTM, thus obtaining the DSM.

The calculation of environmental vulnerability was based on the proposal by Busman and collaborators [28], from the scale of Saaty [29], considering the gravitational movement as the main danger related to extreme precipitation in the region (Tables 2 and 3).

Table 2. Saaty scale applied as in Busman et al. (2016).

\begin{tabular}{|c|c|c|c|c|c|c|c|c|}
\hline $1 / 9$ & $1 / 7$ & $1 / 5$ & $1 / 3$ & 1 & 3 & 5 & 7 & 9 \\
\hline Extremely & $\begin{array}{c}\text { Very } \\
\text { Strongly }\end{array}$ & Strongly & Moderately & \multirow{2}{*}{$\begin{array}{l}\text { Equally } \\
\text { Important }\end{array}$} & Moderately & Strongly & $\begin{array}{c}\text { Very } \\
\text { Strongly }\end{array}$ & Extremely \\
\hline \multicolumn{4}{|c|}{ LESS IMPORTANT } & & \multicolumn{4}{|c|}{ VERY IMPORTANT } \\
\hline
\end{tabular}

Table 3. Saaty scale considering landslides in the district of Mãe Luiza, Natal, RN.

\begin{tabular}{|c|c|c|c|c|c|c|c|c|c|}
\hline & Declivity & Vegetation & Land Use & Pedology & Defluvium & Geomorphology & Geology & Line Sum & $\begin{array}{c}\text { Line } \\
\text { Sum/Sum } \\
\text { of All } \\
\text { Lines }\end{array}$ \\
\hline Declivity & 1 & 3 & 3 & 7 & 5 & 7 & 9 & 35,000 & 0.2605 \\
\hline Vegetation & $=1 / 3$ & 1 & 3 & 3 & 7 & 5 & 9 & 28,333 & 0.2108 \\
\hline Land Use & $=1 / 3$ & $=1 / 3$ & 1 & 5 & 3 & 7 & 9 & 25,667 & 0.1910 \\
\hline Pedology & $=1 / 7$ & $=1 / 3$ & $=1 / 5$ & 1 & $=1 / 3$ & 3 & 9 & 14,010 & 0.1043 \\
\hline Defluvium & $=1 / 5$ & $=1 / 7$ & $=1 / 3$ & 3 & 1 & 5 & 9 & 18,676 & 0.1390 \\
\hline Geomorphology & $y=1 / 7$ & $=1 / 5$ & $=1 / 7$ & $=1 / 3$ & $=1 / 5$ & 1 & 9 & 11,019 & 0.0820 \\
\hline Geology & $=1 / 9$ & $=1 / 9$ & $=1 / 9$ & $=1 / 9$ & $=1 / 9$ & $=1 / 9$ & 1 & 1.6667 & 0.0124 \\
\hline
\end{tabular}

Thus, the final equation for environmental vulnerability in the district of Mãe Luiza, expressed below, was applied to the various layers of the variables under analysis in raster format, using the Quantum GISGNU Raster Calculator tool, applying the map algebra technique. Subsequently, weights were assigned to the classes present in the environmental variables, in proportion to their vulnerability to mass movement (Table 4), in which the values followed Boolean logic [28]. 


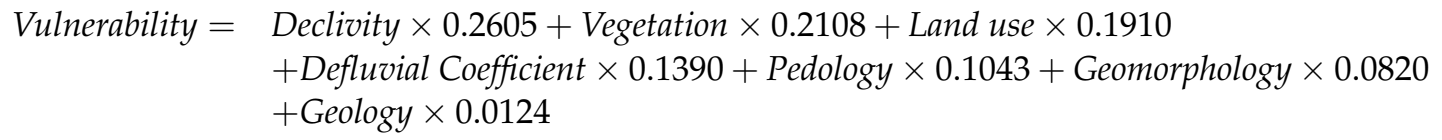

Table 4. Weights for the classes of environmental variables included in the calculation of landslide vulnerability in the district of Mãe Luiza, Natal, RN.

\begin{tabular}{|c|c|c|c|c|c|}
\hline Variable & $\begin{array}{l}\text { Very Low } \\
\text { (1) }\end{array}$ & $\begin{array}{l}\text { Low } \\
(1.5)\end{array}$ & $\begin{array}{l}\text { Medium } \\
\text { (2) }\end{array}$ & $\begin{array}{l}\text { High } \\
(2.5)\end{array}$ & $\begin{array}{l}\text { Very High } \\
\text { (3) }\end{array}$ \\
\hline Declivity* & $0-10^{\circ}$ & $10-20^{\circ}$ & $20-30^{\circ}$ & $30-45^{\circ}$ & $>45^{\circ}$ \\
\hline Vegetation & $\begin{array}{l}\text { Arboreal- } \\
\text { shrub } \\
\text { vegetation }\end{array}$ & $\begin{array}{c}\text { Herbaceous } \\
\text { vegetation }\end{array}$ & - & - & - \\
\hline Land use & - & - & - & $\begin{array}{l}\text { Sidewalks } \\
\text { and access } \\
\text { roads }\end{array}$ & $\begin{array}{c}\text { Homes, } \\
\text { schools, shops, } \\
\text { churches, } \\
\text { health units }\end{array}$ \\
\hline $\begin{array}{l}\text { Defluvium } \\
\text { coefficient }\end{array}$ & $0.10-0.25$ & $0.25-0.30$ & $0.30-0.45$ & $0.45-0.60$ & $>0.60$ \\
\hline Pedology $* * *$ & - & & $\begin{array}{l}\text { Yellow } \\
\text { oxisol }\end{array}$ & $\begin{array}{c}\text { Quartzarenic } \\
\text { neosol }\end{array}$ & \\
\hline Geomorphology *** & & & $\begin{array}{l}\text { Vegetated } \\
\text { coastal dune }\end{array}$ & $\begin{array}{c}\text { Semi- } \\
\text { vegetated } \\
\text { coastal dune }\end{array}$ & $\begin{array}{c}\text { Coastal dunes } \\
\text { not vegetated } \\
\text { and/or } \\
\text { man-made }\end{array}$ \\
\hline Geology $* * *$ & & Barreiras Group & - & - & $\begin{array}{c}\text { Unconsolidated } \\
\text { wind deposit } \\
\text { (dune) }\end{array}$ \\
\hline
\end{tabular}

The vulnerability indices varied between 0 and 3.0, with increments of 0.6 in each of the classes defined in the methodological development, being classified as Very Low (0-0.6), Low (0.6-1.2), Medium (1.2-1.8), High (1.8-2.4) and Very High (2.4-3.0).

\section{Results and Discussion}

Figure 2 shows the life cycle of the atmospheric system based on satellite images, corresponding to the phases of action of the Easterly Wave Disturbance, classified in two distinct moments in time since its reintensification occurred. The moment of initial formation of the EWD occurred on 12 June at 0600 UTC (Figure 2a), when the cloud cover over the ocean was observed moving westwards in the vicinity of the mainland. The maturation phase of the system occurred around 1600 UTC on 13th June (Figure 2b), with clouds of great vertical development and intense convective activity, evidenced by the temperature values of the top of the clouds that reached $-55^{\circ} \mathrm{C}$. The dissipation occurred at 0930 UTC on the 14th of June (Figure 2c), with shallow clouds being observed along the coast.

The system reintensified on the 14th at 1200 UTC (Figure 2d), corresponding to its second maturation, which occurred at 0000 UTC on the 15th of June (Figure 2e). At this moment, there was greater convective activity and clouds with pronounced vertical development, typical of cumulonimbus clouds, which are responsible for intense precipitation. Subsequently, the system dissipated at 1800 UTC on the 15th June (Figure 2f), leaving the weather over the east coast of Rio Grande do Norte unstable. 


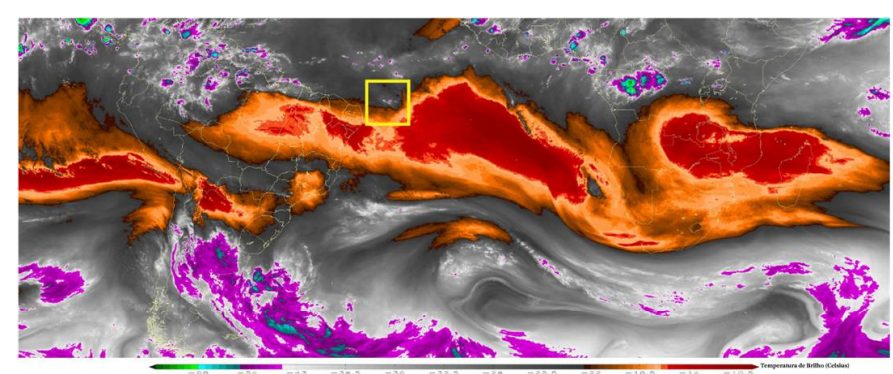

a) Formation - 0600UTC/12062014

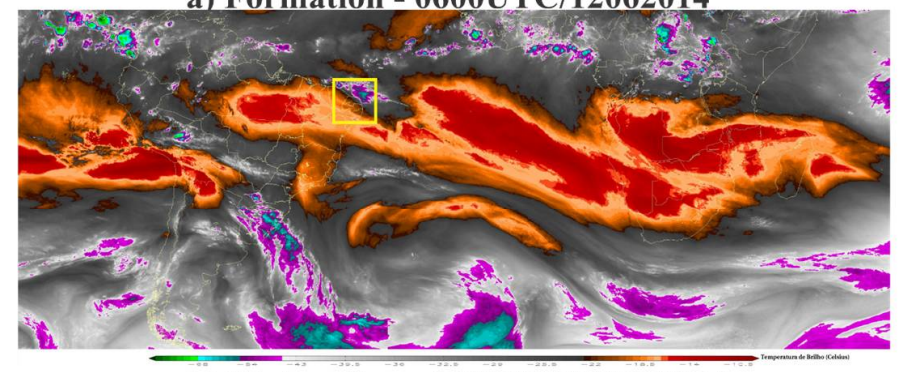

b) Maturation - 1600UTC/13062014

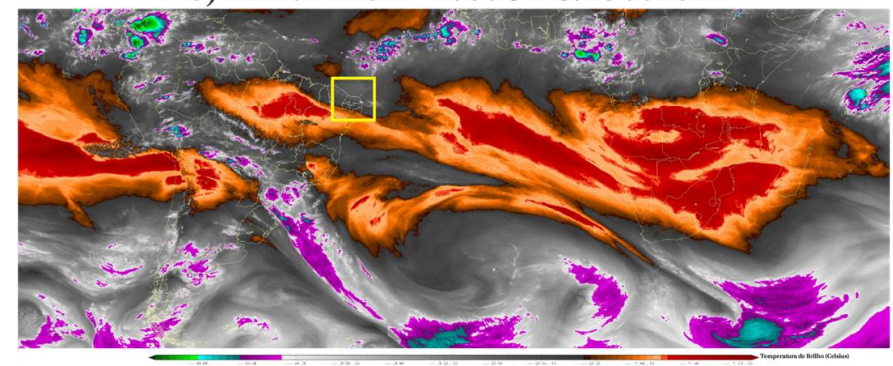

c) Dissipation - 0930UTC/14062014

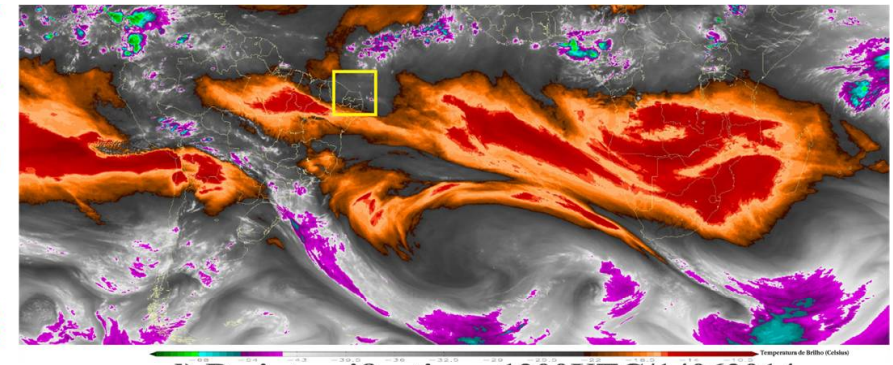

d) Re-intensification - 1200UTC/14062014

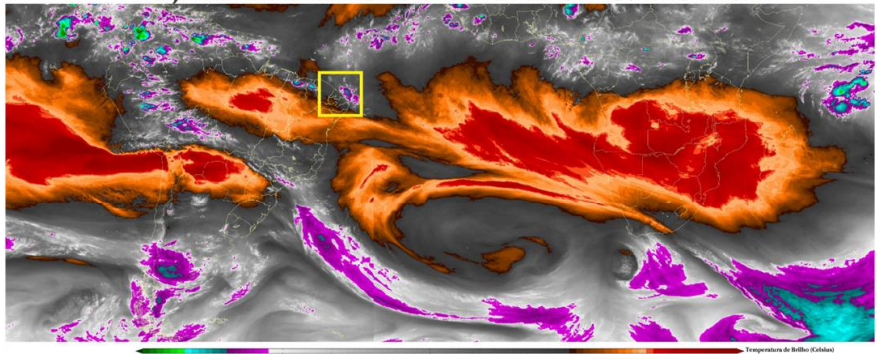

e) Maturation 2- 0000UTC/15062014

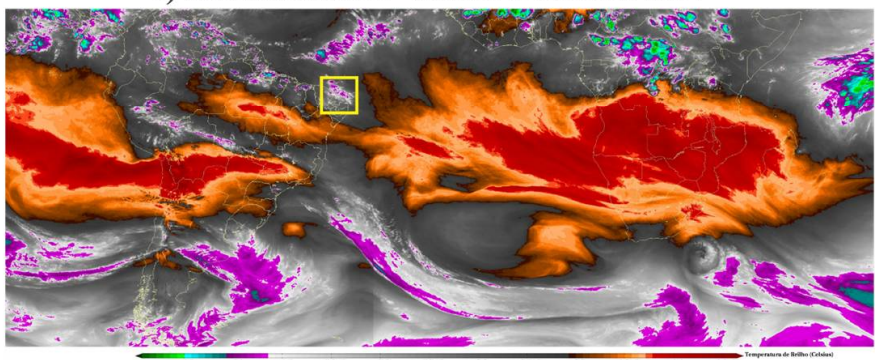

f) Dissipation 2- 1800UTC/15062014

Figure 2. Satellite images showing the phases of (a) formation, (b) maturation, (c) dissipation, (d) re-intensification, (e) 2nd maturation and (f) 2nd dissipation. The yellow rectangle represents the identification of the evolution of the system.

The mass movement event that took place in the district of Mãe Luiza from 13-15 June 2014 was aggravated by extreme rainfall resulting from the EWD, a very influential atmospheric system affecting the rainfall regime in cities located in the eastern part of Northeast Brazil (NEB). As stated in previous studies, the mentioned disaster generated a large volume of sediment and debris, in the order of approximately $70,000 \mathrm{~m}^{3}$, causing the collapse of 30 homes, which were consequently left uninhabitable, and causing economic losses to 78 households [30]. Additionally, there were major obstacles to urban mobility caused by the accumulation of material on public roads. This region also has a strong tourist flow. Indeed, these roads were built to handle the traffic generated by matches of the World Cup in 2014.

Several studies developed regarding the east coast of Northeast Brazil have indicated the EWD is an atmospheric system that propels heavy rains [26,31,32]. The factors described above exacerbated the natural disaster caused by excessive precipitation. This event mainly affected people who were highly vulnerable, causing social instability in different segments, such as health, education, social assistance and housing, in addition to the loss of human lives.

The daily accumulated precipitation on the days of the event was greater than $100 \mathrm{~mm}$, although this was slightly lower (around $80 \mathrm{~mm}$ ) in some districts located to the west of the city. Figure 3 shows the accumulated rainfall in three hours, according to the phases of the atmospheric system in question. This considered the periods beforehand and afterward, determined by means of satellite images for each of the phases under analysis. The precipitation in the maturation periods of the system was substantial, considering the three-hour accumulation, where some areas registered more than $60 \mathrm{~mm}$ of rain. This behavior comes from the system phase, in which there is the greatest convective activity 
during the period of development, with clouds having large vertical development and top temperatures of $-55^{\circ} \mathrm{C}$ to $-60^{\circ} \mathrm{C}$.

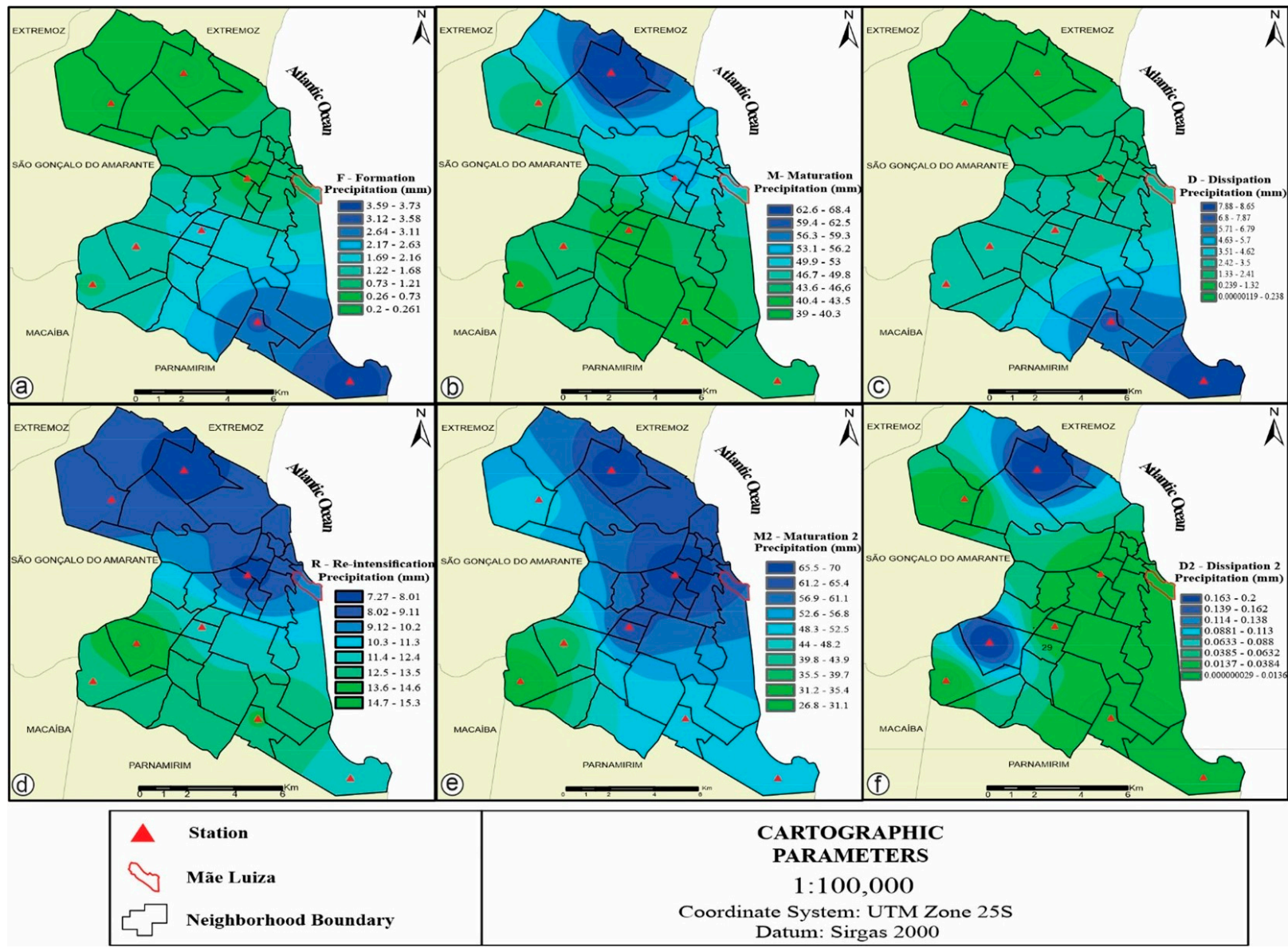

Figure 3. Accumulated rainfall in the city of Natal in three hours according to the phases of (a) formation, (b) maturation, (c) dissipation, (d) re-intensification, (e) 2nd maturation, (f) 2nd dissipation.

According to previous studies, the highest average values of maximum daily precipitation in Natal typically occur in June, with a record of $94.4 \mathrm{~mm}$. Their analysis was performed using the return period for extreme events in the city of Natal, adopting extreme value distribution (EVD) models. In addition, the authors estimated that the probability of rainfall above $80 \mathrm{~mm} /$ day in the city in that month was $55.1 \%$ [33,34].

Events of intense precipitation during June in the eastern part of Northeast Brazil are quite frequent, since this month is considered the height of the rainy season in the region (April to July) [33,35,36]. Easterly Wave Disturbances are associated systems, since this is the period of greatest intensity [37-39], being responsible for 70\% of the precipitation [40].

Anomalies of wind magnitude and the vertically integrated moisture flux are shown in Figures 4 and 5, respectively. In the formation of the EWD, intense positive anomalies of wind speed are observed in much of the Brazilian continent, extending to the South Atlantic Ocean, with values of 1 and greater than $7 \mathrm{~m} / \mathrm{s}$, respectively. Specifically, in the state of Rio Grande do Norte, the values vary from 1 to $5 \mathrm{~m} / \mathrm{s}$. The vertically integrated moisture flux is less intense in this formation phase in the coastal part of the state, with values around $840-960 \mathrm{~kg} / \mathrm{s}$. However, regions of greater intensity are observed in part of the South Atlantic, with values greater than $1200 \mathrm{~kg} / \mathrm{s}$. Thus, the strong wind anomalies tend to transport moisture from the ocean to the continent. 


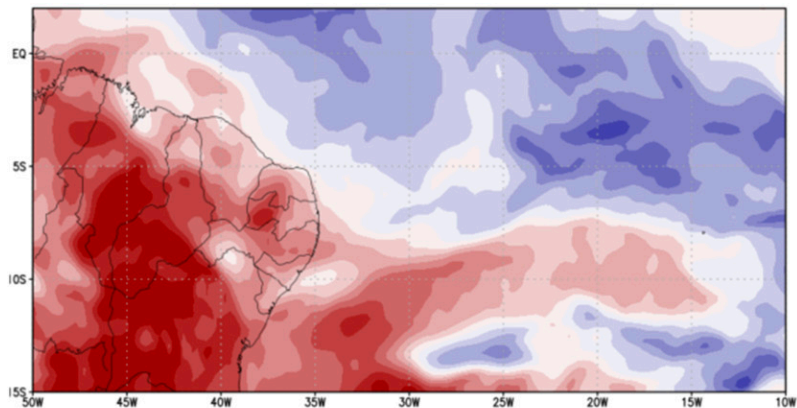

a) Formation - 0600UTC/12062014

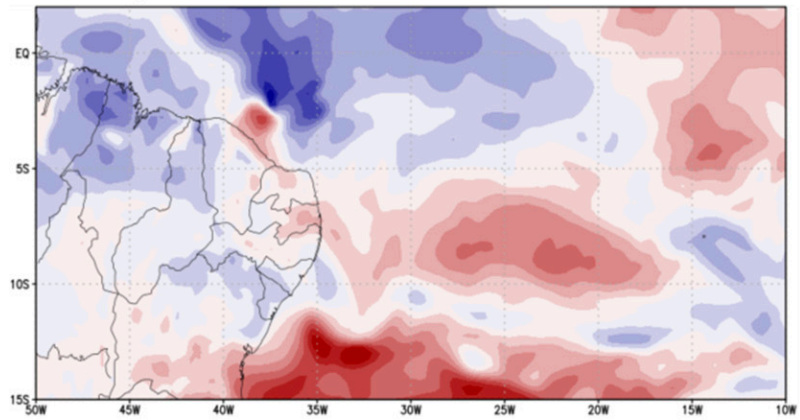

b) Maturation - 1600UTC/13062014

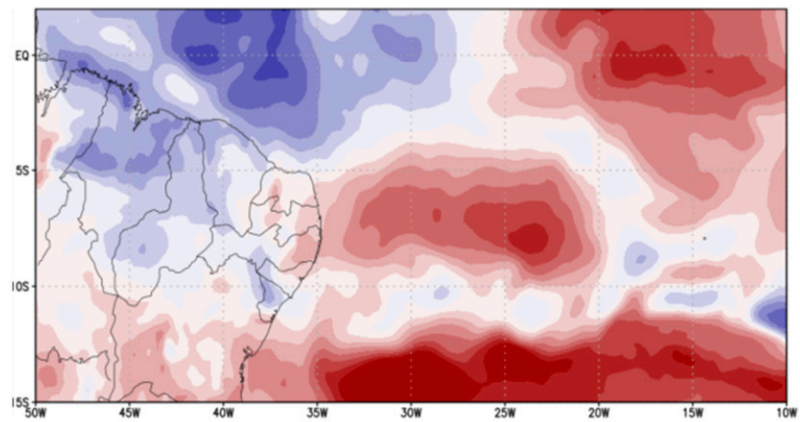

c) Dissipation - 0930UTC/14062014

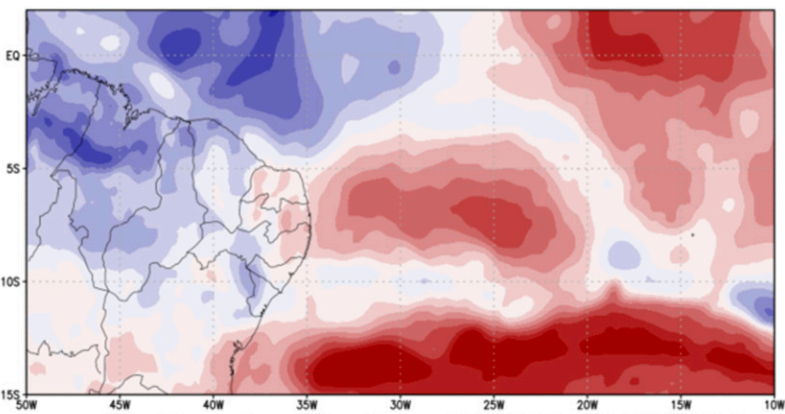

d) $\mathrm{Re}$-intensification $-1200 \mathrm{UTC} / 14062014$

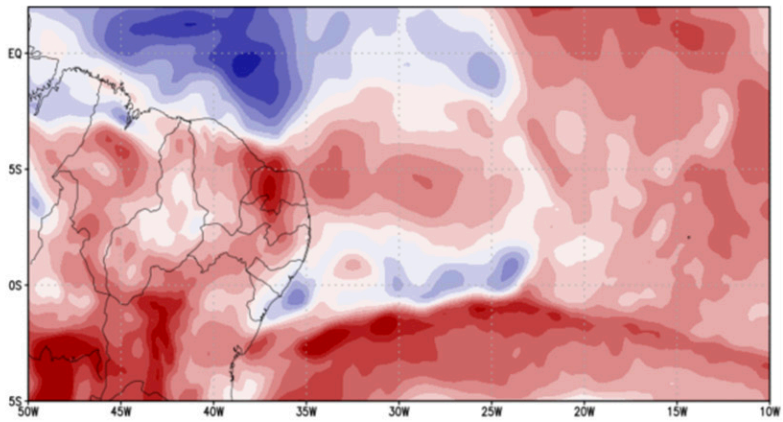

e) Maturation 2 - 0000UTC/15062014

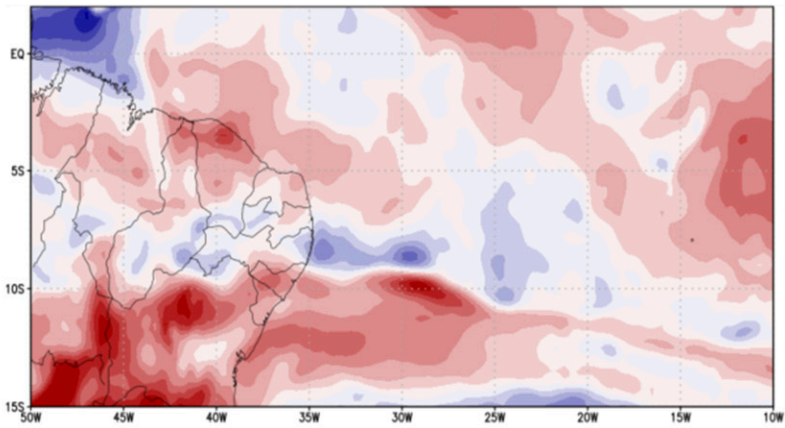

f) Dissipation 2 - 1800UTC/15062014

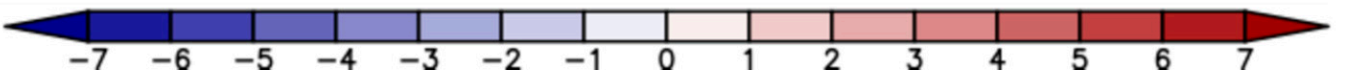

Figure 4. Anomalies of the wind speed in $\mathrm{m} / \mathrm{s}$ for the phases (a) formation, (b) maturation, (c) dissipation, (d) reintensification, (e) 2nd maturation, (f) 2nd dissipation of the Eastern Wave Disturbance.

In the event studied here, the first maturation phase coincided with the greatest convective activity of the system, which was marked by the highest rainfall. The system started maturing on 13 June, with anomaly values for the wind speed over the South Atlantic greater than $3 \mathrm{~m} / \mathrm{s}$. Normal conditions were observed for that moment in Rio Grande do Norte, although considering the moisture flux, the values for the state were not as extreme.

Even though the system dissipated at first, there was instability left in the region and it reintensified, passing through another cycle of maturation and dissipation, with high wind speed anomaly values. In this second cycle, an anomaly of $6 \mathrm{~m} / \mathrm{s}$ and an intense moisture flux occurred along the entire east coast of the state, with a record of $1320 \mathrm{~kg} / \mathrm{s}$. This situation may have favored an upward movement, with vertical development of clouds and heavy rains throughout this cycle, presenting the highest precipitation. 


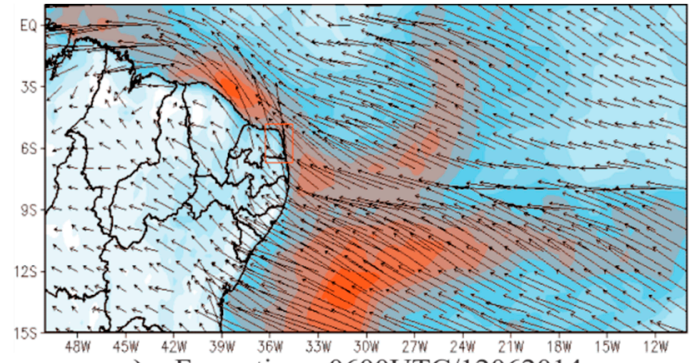

a) Formation - 0600UTC/12062014

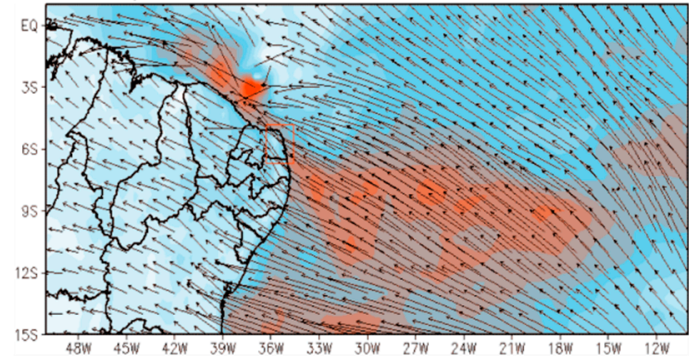

b) Maturation - 1600UTC/13062014

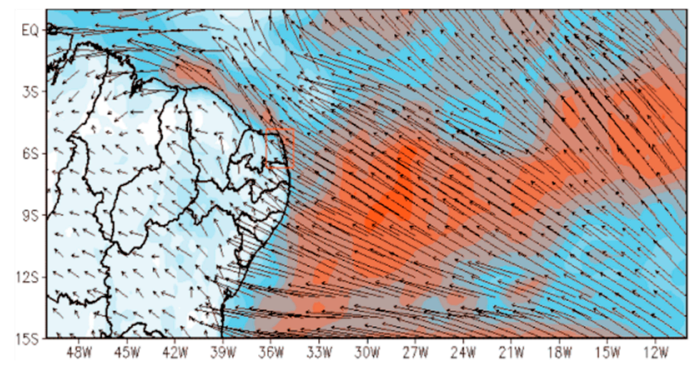

c) Dissipation - 0930UTC/14062014

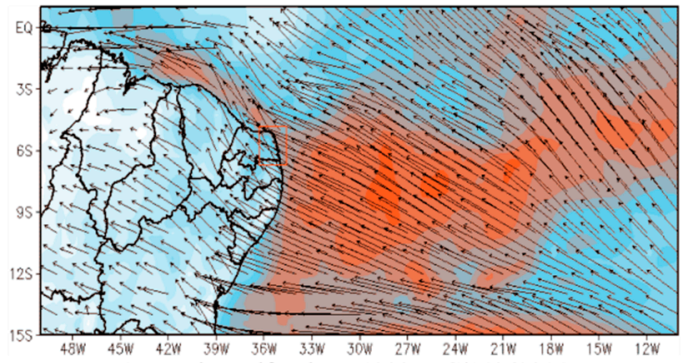

d) Re-intensification - 1200UTC/14062014

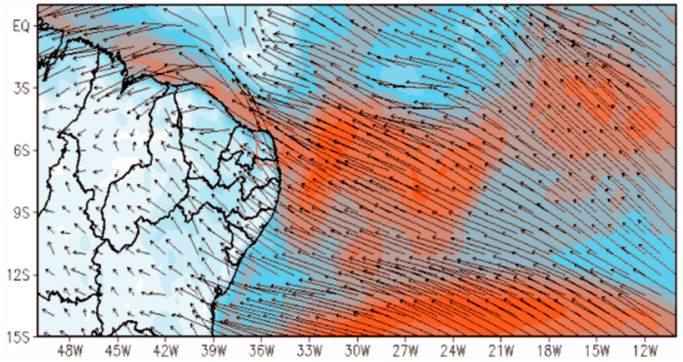

e) Maturation 2 - 0000UTC/15062014

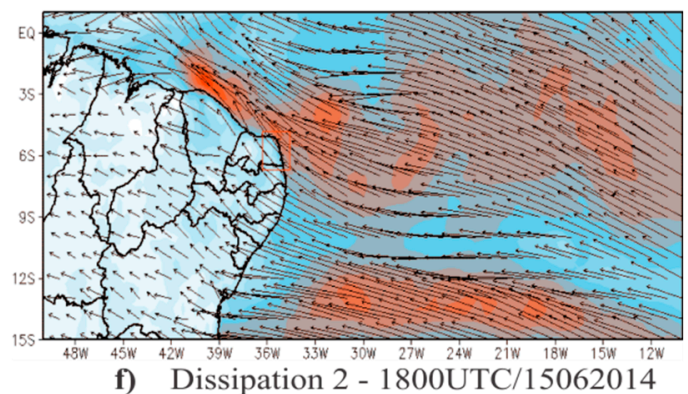

f) Dissipation 2 - 1800UTC/15062014

$\begin{array}{llllllllllll}120 & 240 & 360 & 480 & 600 & 720 & 840 & 960 & 1080 & 1200 & 1320 & 1440\end{array}$

Figure 5. Specific moisture flux ( $\mathrm{kg}$ water/ $\mathrm{kg}$ air) vertically integrated in the phases (a) formation, (b) maturation, (c) dissipation, (d) re-intensification, (e) 2nd maturation, (f) 2nd dissipation of the Eastern Wave Disturbance.

Analyzing the synoptic environment of that event, researchers considered the vertical speed, wind speed, relative vorticity and specific humidity, and observed that in all the analyses, it was possible to identify propitious factors in the formation of the EWD [8,9]. Its formation on 12 June 2014 was accompanied by an extension of the convective activity present in the ICTZ, with its propagation displaced from east to west, at a propagation speed of approximately $7 \mathrm{~m} . \mathrm{s}^{-1}$ and length of initial wave of around $2000 \mathrm{~km}$. The weather system reached the continent on 13th June, showing high Standardized Precipitation Index values.

The second dissipation phase occurred on 15 June, characterized by weakening wind speed with an anomaly below $2 \mathrm{~m} / \mathrm{s}$. In addition, a reduction in humidity on the east coast did not immediately occur due to the instability left in the atmosphere. The moisture flux reached values above $1080 \mathrm{~kg} / \mathrm{s}$. This behavior is expected after the action of any atmospheric system, since the destabilizations cause a return to normal conditions.

Figure 6 shows the integrated vertical moisture fluxes from 1000 to $300 \mathrm{hPa}$ for the phases of the Eastern Wave Disturbance, with the respective contributions from the east, west, north and south. The largest fluxes were recorded on the eastern edge of the region, contributing to the gain of moisture for the development of the system. The largest influx was observed at the eastern edge in maturation phase 2 (Figure 6e), in the order of $1.5488 \times 10^{7} \mathrm{~kg} / \mathrm{s}$, with a greater loss of moisture observed along the western edge during dissipation phase 2 , with values of $-1.3621 \times 10^{7} \mathrm{~kg} / \mathrm{s}$. In all the analyzed phases, the convergence of the moisture flux over the area was greater than $1.0 \times 10^{7} \mathrm{~kg} / \mathrm{s}$, with the highest value observed in maturation phase 2 of $2.65 \times 10^{7} \mathrm{~kg} / \mathrm{s}$. 

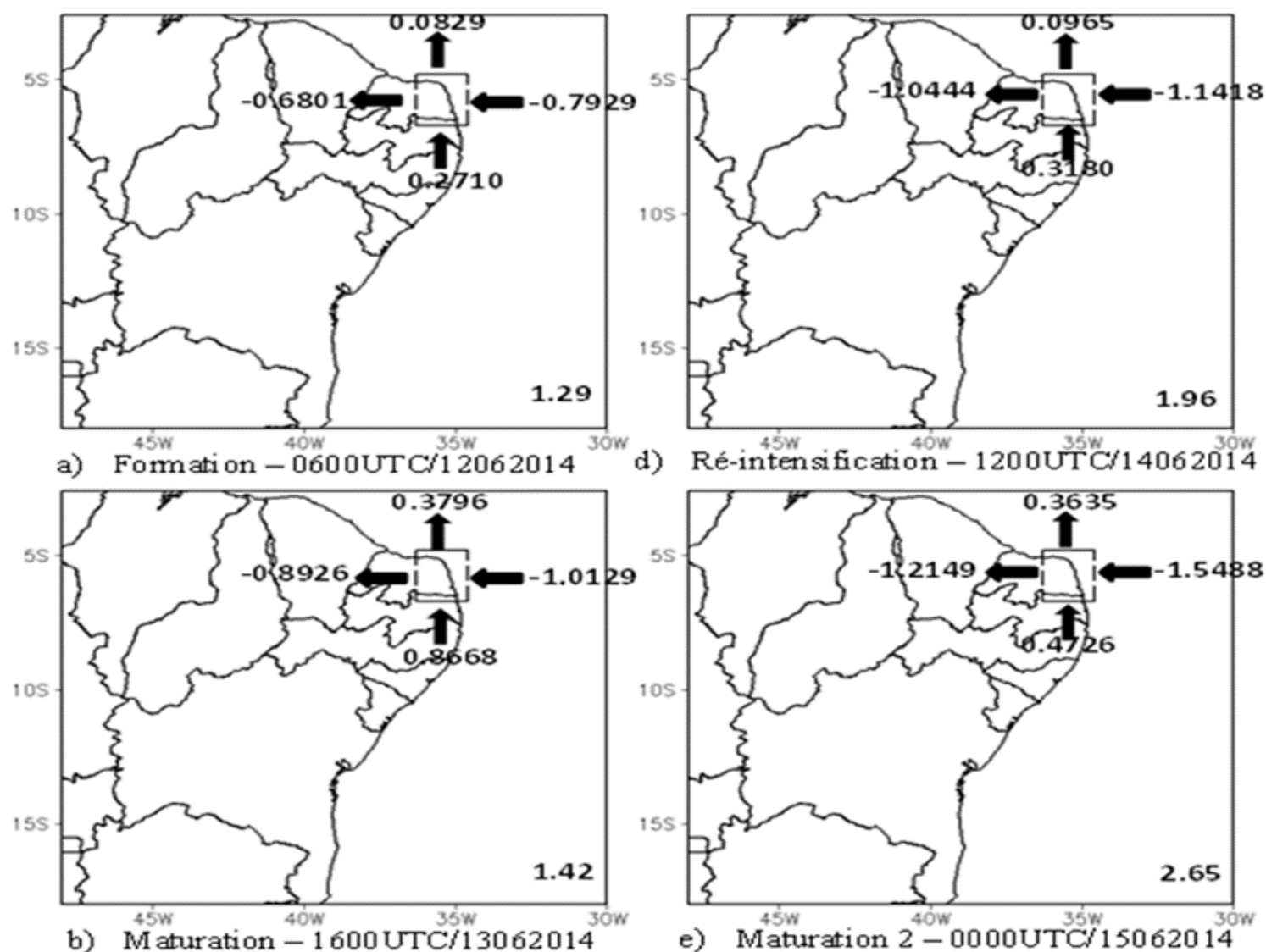

b) Maturation - $1600 \mathrm{UTC} / 13062014$
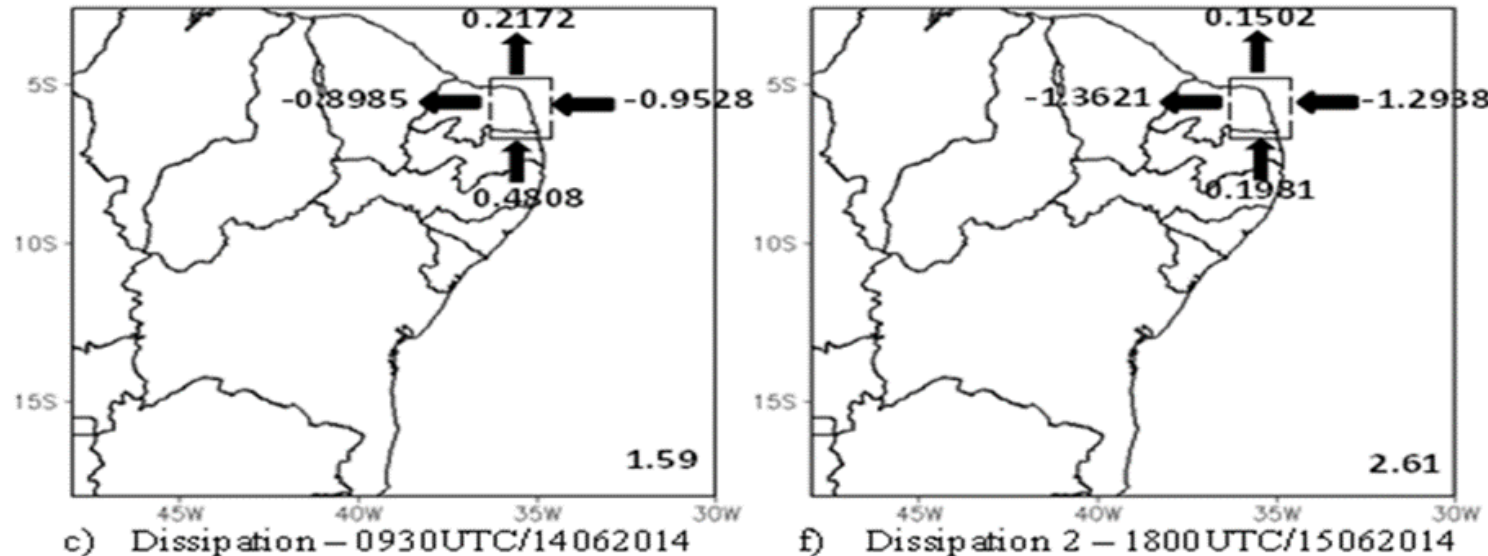

Figure 6. Moisture flux vertically integrated from 1000 to $300 \mathrm{hPa}$, along the representative edges of table $107 \mathrm{~kg} / \mathrm{s}$.

The highest moisture influx occurred at the eastern edge of the region, strongly associated with the proximity to the ocean, influenced by the trade winds. Researchers analyzed the moisture flux of precipitation system events on the NEB east coast and observed that the region is characterized by the convergence of humidity borne by the trade winds, east waves and breezes associated with the topography, in addition to the circulation and the transport of moisture from the ocean towards the continent, where it contributes to feeding the convection over the surface. This caused the occurrence of landslides in the respective regions of those studies [31,32].

Figure 7 shows the energy terms $\mathrm{AZ}, \mathrm{AE}, \mathrm{KZ}$ and $\mathrm{KE}$, as well as the $\mathrm{CZ}, \mathrm{CE}, \mathrm{CA}$ and $\mathrm{CK}$ conversions for the oceanic region where the EWD operates. Considering the full extent of the EWD's influence between the 12 and 15 June 2014, the terms of energy and the conversions between them regarding the propagation and development phases of this meteorological system are discussed. 

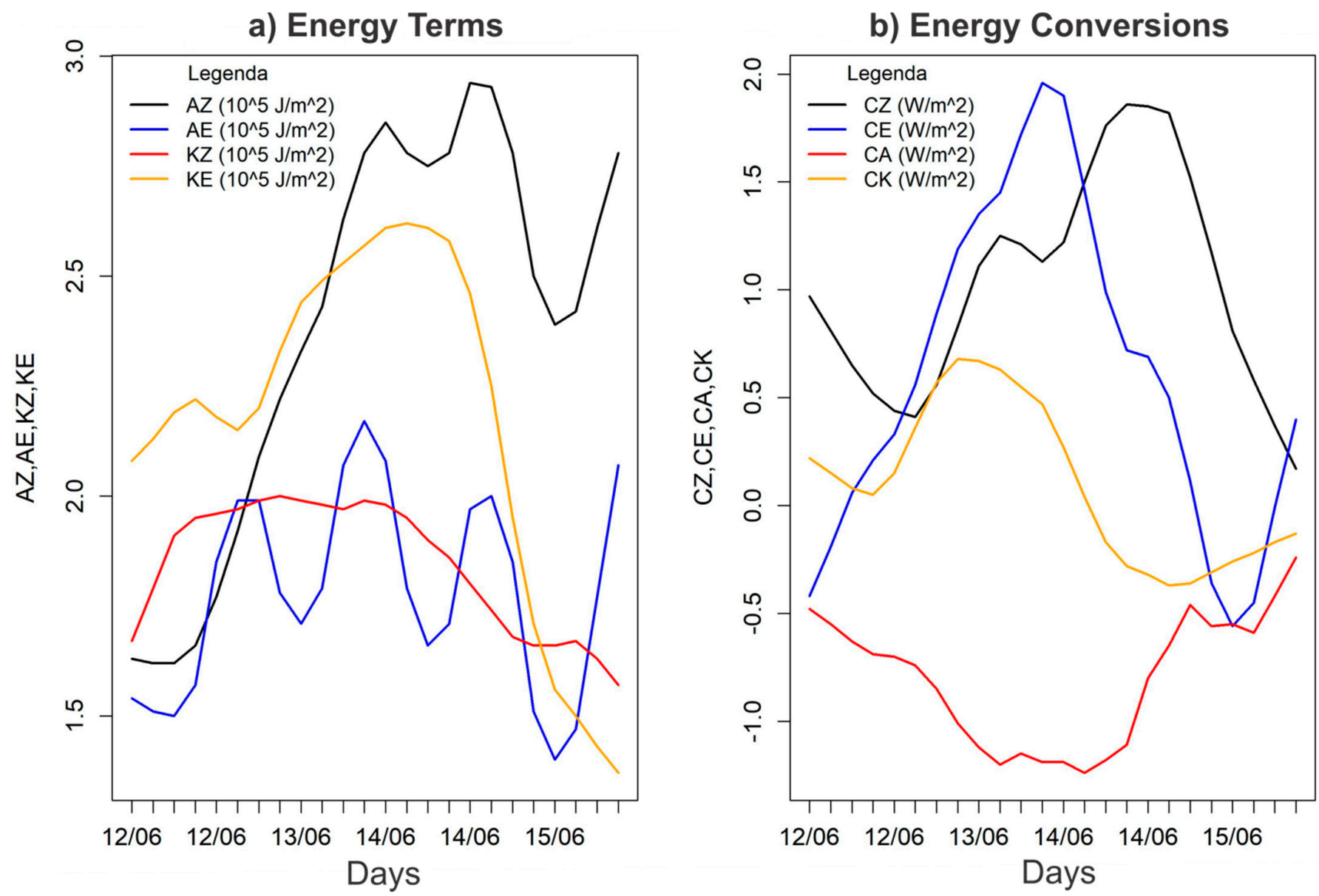

Figure 7. Variations and conversions of energy terms between 12 and 15 June 2014 in the region comprising the continental and oceanic parts of the east coast of Northeast Brazil affected by the EWD.

The energy terms (Figure 7a) that stood out quantitatively in relation to the others during the development of the EWD were AZ (zonal potential available energy) and KE (kinetic disturbance energy). This shows that the generation of potential available energy and the generation of kinetic energy from the disturbance were determinants for the intensification and maintenance of the EWD.

The energy term AZ had values between $1.610^{5} \mathrm{~J} / \mathrm{m}^{2}$ and $2.910^{5} \mathrm{~J} / \mathrm{m}^{2}$, presenting two peak values on 14th June, one at 0000 and another at 1800 UTC, showing a variation with the daytime cycle, since it is associated with air temperature. This term is related to the incidence of solar radiation for different latitudes. This was the main source of heat to start the formation of the disturbance.

The values of KE ranged between $1.3 \times 10^{5} \mathrm{~J} / \mathrm{m}^{2}$ and $2.6 \times 10^{5} \mathrm{~J} / \mathrm{m}^{2}$, reaching a maximum value in the first maturation period of the meteorological system. Figure $7 \mathrm{a}$ shows that KE had a higher value $\left(2 \times 10^{5} \mathrm{~J} / \mathrm{m}^{2}\right)$ than $\mathrm{AZ}\left(1.6 \times 10^{5} \mathrm{~J} / \mathrm{m}^{2}\right)$ in the initial phase of the EWD formation, but it accompanied the increase in AZ less intensely and began to decay while AZ still presented high values.

Finally, the energy terms with the lowest magnitude were KZ (zonal kinetic energy) and $\mathrm{AE}$ (potential disturbance energy). AE presented values oscillating between $1.4 \times 10^{5} \mathrm{~J} / \mathrm{m}^{2}$ and $2.1 \times 10^{5} \mathrm{~J} / \mathrm{m}^{2}$, with three peaks. The wave behavior of AE in Figure $7 \mathrm{a}$ is linked to the variability of the temperature gradient during the propagation of the EWD. The term KZ, on the other hand, presented energy values between $1.5 \times 10^{5} \mathrm{~J} / \mathrm{m}^{2}$ and $1.9 \times 10^{5} \mathrm{~J} / \mathrm{m}^{2}$, and significantly increased only in the beginning of the development of the meteorological disturbance, related to the transport of this energy from adjacent regions. 
The energy conversions (Figure $7 \mathrm{~b}$ ) of the studies showed that the highest conversion rate was the transformation of the available potential energy of the disturbance into kinetic energy of the disturbance (KE), followed by the conversion of the $\mathrm{CZ}$ type. During the formation of the EWD, the rate of conversion of KE increased, reaching its maximum value just before the maturation of the disturbance. This type of conversion is related to upward movements of hot air and downward movements of cold air, which explains the development of the meteorological phenomenon until it reached maturity. Conversion rates of the $\mathrm{CZ}$ and $\mathrm{KE}$ types reflect the vertical shear of the average flux of the atmosphere, and the increase in these rates shows that the EWD receives energy through the conversion of potential energy associated with the average horizontal temperature gradient into kinetic energy [21].

The CK conversion term had positive values and increased during the intensification of the EWD, while as the disturbance dissipated, the CK value decreased and started to have negative values. Negative $\mathrm{CK}$ values indicate the extraction of kinetic energy from the zonal flux by the EWD.

The energy conversion of the CA type had negative values during the whole period of the weather disturbance, and its values decreased more as the EWD intensified, and increased again during the dissipation. These negative values denote the conversion of $\mathrm{AE}$ (potential disturbance energy) into AZ (zonal available potential energy).

In light of the high rainfall levels in the city of Natal described above, our objective was to identify the physical conditions of the district of Mãe Luiza in order to measure its exposure to landslides based on methodological elements with high precision, resolution and accuracy.

\section{Environmental Vulnerability}

Initially, we sought to represent the terrain relief in order to identify the influence of variations in altitude of the surface being studied. Figure 8 presents the representation of the Digital Terrain Model (Figure 8a), which for measurement took into account only the terrain conditions and the Digital Surface Model (Figure 8b), which is influenced by the vegetation and buildings present in the region. It can be observed that the area has high values, with height values varying from 30 to $75 \mathrm{~m}$ in practically the entire area under study. Regions with high declivity are at a greater risk of mass movement events due to the physical characteristics. These are strongly aggravated by human activity, such as the removal of vegetation and construction of paved roads, which greatly increase the runoff from rainfall. In general, steep hillsides are not suitable for human occupation.

Figure 9 shows the spatial distribution of the environmental variables under analysis through thematic maps for the district of Mãe Luiza. Considering the declivity of the region (Figure 9a), it is possible to observe areas that became flat because of human occupation, or dune tops with variations between 0 and $5^{\circ}$ (shades of green and yellow). The slopes are approximately between $10^{\circ}$ and $65^{\circ}$ (shades of red) and the sub-vertical values (shades of black) are related to the edges of buildings and sidewalks. 

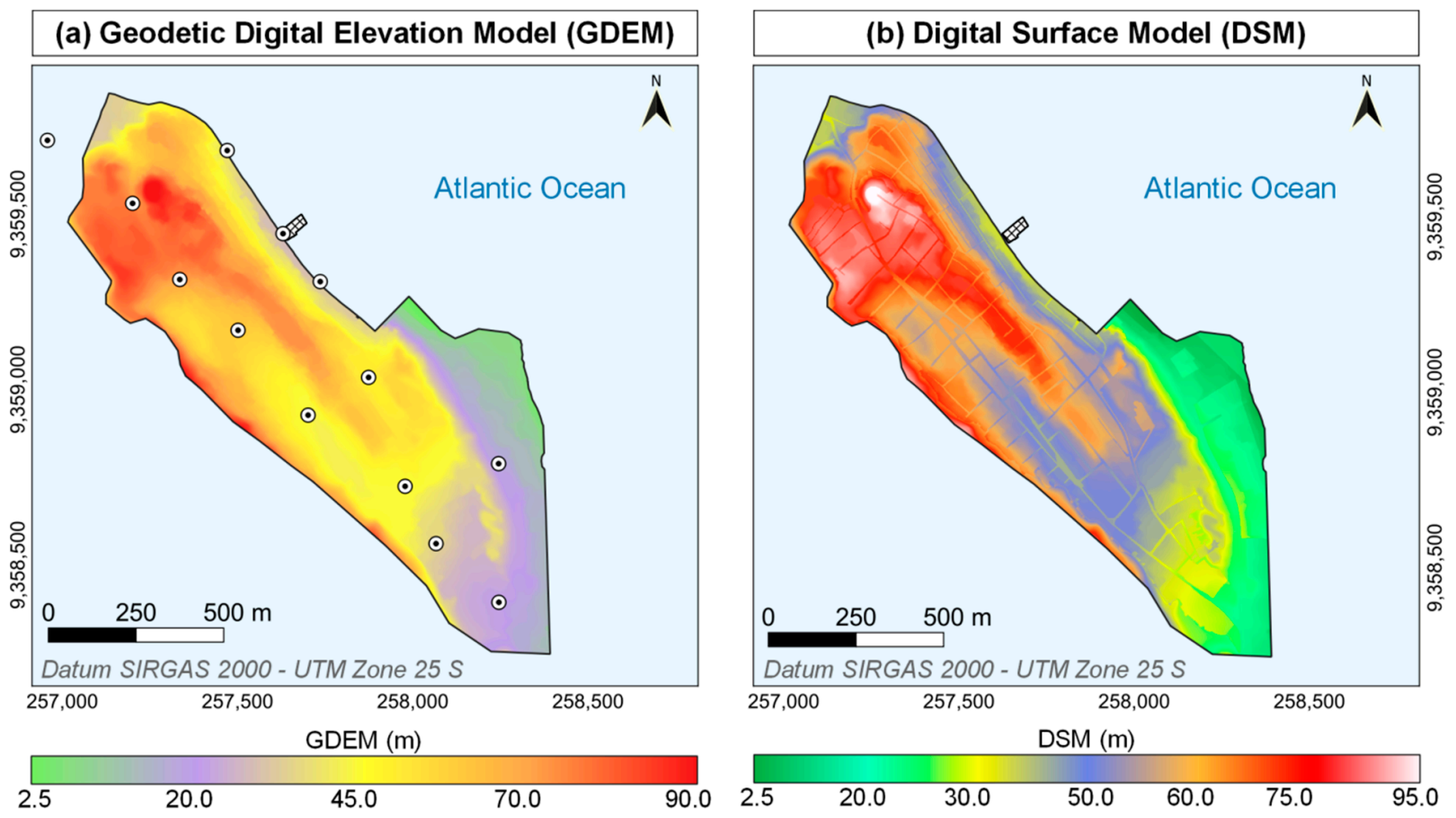

\section{Map Legend \\ Mãe Luiza Boundaries}

Mãe Luiza Staircase

$\odot$ Geodetic Control Points

Figure 8. Digital Terrain Model with geodetic calibration (a) and Digital Surface Model (b) for the district of Mãe Luiza, Natal, Rio Grande do Norte.

From a geological standpoint (Figure 9b), the district of Mãe Luíza is predominantly based on recent coastal wind deposits (dune fields). The northern, northeastern and southeastern borders of Mãe Luiza are restricted by rocky outcrops, which are the substrate of the dune fields. The geomorphology (Figure 9c) is predominantly dune relief, sometimes with anthropized portions, sometimes vegetated and sometimes with exposed soil. Regarding pedology (Figure 9d), yellow latosols cover the rocky outcrop areas, but the predominance is quartzarenic neosols, related to the dominant presence of the dune fields.

The defluvium coefficient (Figure 9e), despite the high porosity and infiltration capacity of the dune sediments, is low due to the high impermeability caused by the urbanization of the district [41]. It is highest in the central part (0.44), northern part (0.52) and northeastern part (0.61), whose runoff heads to the coast, which suffered the most from the landslide event.

The vegetation in the region (Figure 9f) is scanty due to deforestation of much of the district, leaving a fringe of dunes with arboreal-shrub vegetation, mainly on the west edge of the district, bordering a preserved site (Dunes Park). Some patches of trees and herbaceous vegetation occur in the southeastern portion of the district. In the case of land use (Figure 9g), the majority is one-story homes, interspersed with small commercial establishments with similar construction as the homes. The access roads are paved with asphalt and/or cobblestones, both of which are waterproofing materials. The undeveloped areas (although with slight anthropization) are concentrated on the southeastern edge of the district, which is crossed by a state highway. 


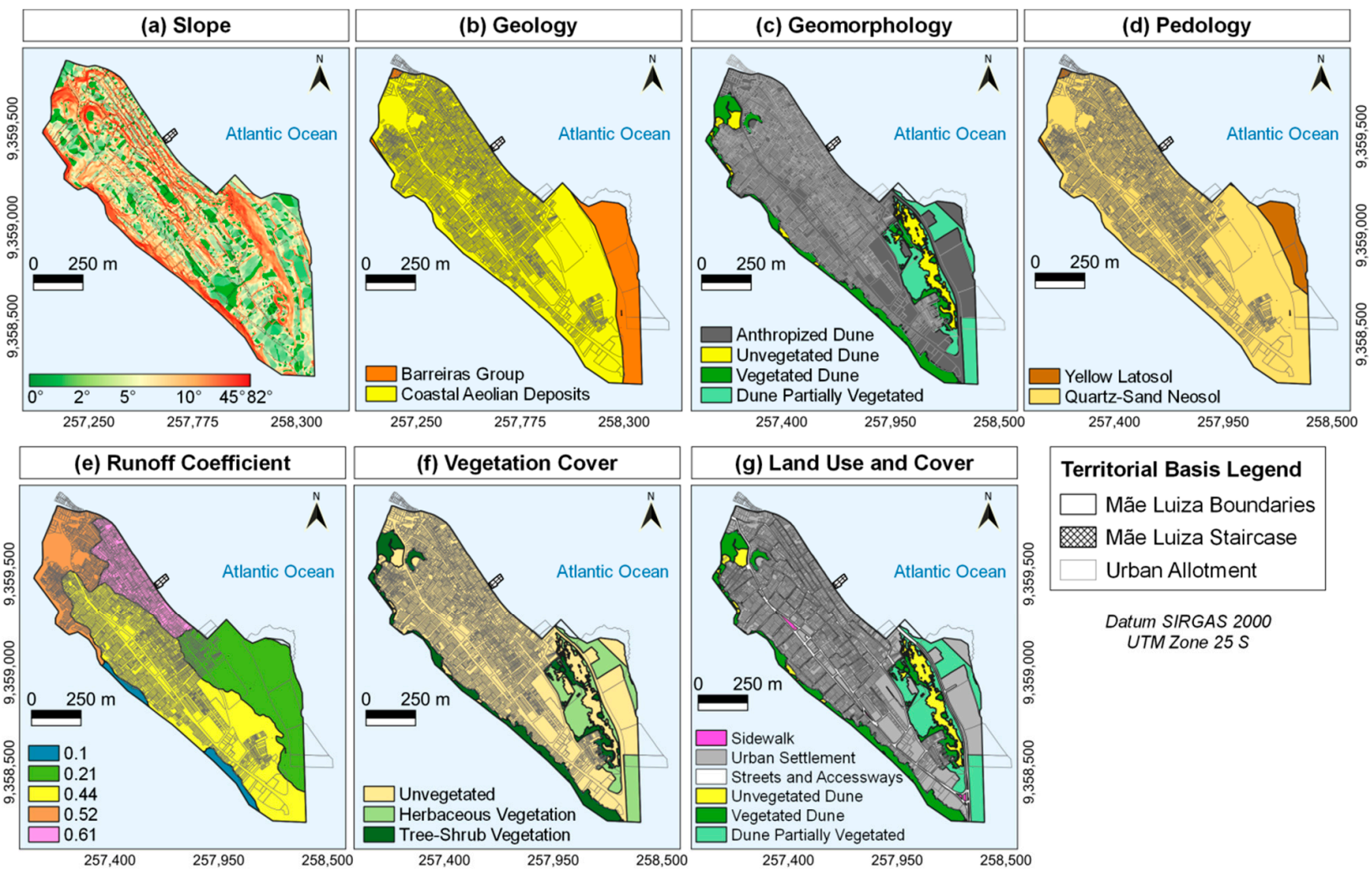

Figure 9. Thematic maps of environmental factors taken into account in the vulnerability of the district of Mãe Luiza, Natal, Rio Grande do Norte.

After the individual identification of all the environmental variables under analysis, it was possible to integrate all the elements, through map algebra, in order to measure the environmental vulnerability of Mãe Luiza (Figure 10). Thus, areas with very low vulnerability are rare in the area, which showed the predominance of high and very high vulnerability, along with areas of medium vulnerability (preserved vegetated areas with slight anthropization). Regions with steep slopes and intense soil impermeability presented high and very high vulnerabilities, notably in the northeastern part, where the landslide occurred, which presented a high defluvium coefficient. In this region and in the central part of the district, the access roads that mainly run parallel to the runoff favor increased vulnerability.

Researchers attributed the aforementioned mass movement event in June 2014 to negligence and problems related to territorial planning and ordering [30,42]. In turn, studies reported that a large part of the urbanized area of the district of Mãe Luiza had high or very high social vulnerability, which increased the population's exposure to mass movement events $[43,44]$. In the case of the Mass Movement Exposure Index, the areas identified with the highest levels were those with the greatest environmental vulnerability, corresponding to stretches of steep slopes (greater than $30^{\circ}$ ) and dunes, mainly oriented toward the $\mathrm{NE}$, the latter coinciding with densely inhabited sectors located in the northeastern and southwestern areas of the district. 


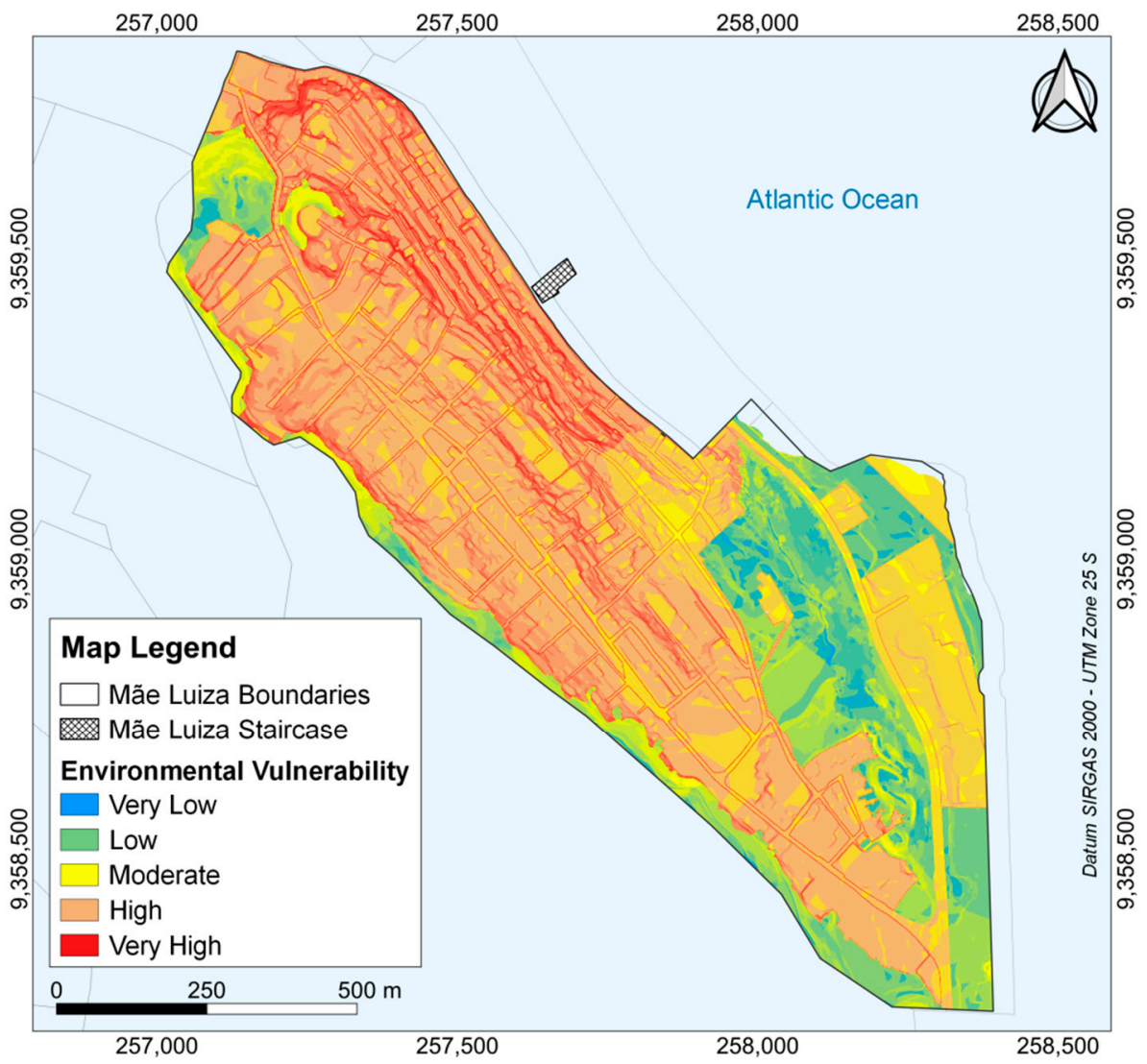

Figure 10. Environmental vulnerability for the district of Mãe Luiza, Natal, Rio Grande do Norte.

\section{Conclusions}

This study showed that the synoptic characteristics of the Easterly Wave Disturbance favored the occurrence of the extreme precipitation event examined here. The atmospheric parameters were favored by the location of the city of Natal, which is close to the ocean and thus subject to ocean-atmosphere interaction. Another determining factor was the influence of the trade winds, which are strongest along the eastern coast of the state. This ocean-atmosphere interaction in the region of Natal causes excessive precipitation, leading to the destabilization of public services for urban mobility and aggravating the effects of natural disasters, including the landslide in the district of Mãe Luiza.

The physical-environmental conditions were of fundamental importance to characterize and measure the local environmental vulnerability through information with high precision, resolution and accuracy, enabled by the new methods used for the elaboration of digital models. These models made it possible to visualize and calculate the areas of the district with the greatest environmental vulnerability. The diagnosis was mainly high vulnerability to mass movements, especially in the eastern portion where there are more critical areas than in the others. The regions with low environmental vulnerability in the district were those still protected from erosion and mass movement by trees and shrubs.

It is worth mentioning that extreme natural events are only characterized as disasters when they affect local residents. Understanding the various weather/climate factors and atmospheric, geological and social factors involved in natural disasters is extremely important. This article contributes to the formulation of more effective public policies by municipal authorities and experts to mitigate the risks of and vulnerability to mass movement events. In this process, the government's role is fundamental for proper urban planning and environmental preservation. 
Author Contributions: Conceptualization, M.S.M.R., L.d.M.B.A., M.H.C.S. and K.C.L.; methodology, M.S.M.R., K.C.L. and V.E.A.; software, M.S.M.R., M.D.L.C., J.E.d.C.A.A. and L.R.d.S.G.P.; validation, M.S.M.R., L.d.M.B.A., M.H.C.S., K.C.L., V.E.A., L.d.M.B.A., M.D.L.C. and J.E.d.C.A.A.; formal analysis, M.S.M.R. and M.H.C.S.; writing-original draft preparation, M.S.M.R.; writing-review and editing, M.S.M.R., K.C.L. and V.E.A.; visualization, M.S.M.R.; supervision, M.S.M.R., L.d.M.B.A. and M.H.C.S. All authors have read and agreed to the published version of the manuscript.

Funding: This research received no external funding.

Institutional Review Board Statement: Not applicable.

Informed Consent Statement: Not applicable.

Data Availability Statement: The data used in this manuscript are available by writing to the corresponding authors.

Acknowledgments: We thank the Department of Atmospheric and Climatic Sciences of the Federal University of Rio Grande do Norte, for providing the necessary funds for publication of the present work.

Conflicts of Interest: The authors declare no conflict of interest.

\section{References}

1. Mattedi, M.A.; Butzke, I.C. A relação entre o social e o natural nas abordagens de hazards e de desastres. Ambiente Soc. 2001, 9, 93-114. [CrossRef]

2. Narváez, L.; Lavell, A.; Pérez, G. La Gestión del Riesgo de Desastres. Secretaría General de la Comunidad Andina. 2009. Available online: https: / repositorio.gestiondelriesgo.gov.co/handle/20.500.11762/19759 (accessed on 27 January 2021).

3. Welle, T.; Birkmann, J. The World Risk Index-An approach to assess risk and vulnerability on a global scale. J. Extrem. Events 2015, 2, 1550003. [CrossRef]

4. Pielke, R., Jr.; Carbone, R.E. Impactos do tempo, previsões e políticas: Uma perspectiva integrada. Bull. Am. Meteorol. Soc. 2002, 83, 393-406. [CrossRef]

5. Du, H.; Alexander, L.V.; Donat, M.G.; Lippmann, T.; Srivastava, A.; Salinger, J.; Kruger, A.; Choi, G.; He, H.; Fujibe, F.; et al. Precipitation from persistent extremes is increasing in most regions and globally. Geophys. Res. Lett. 2019, 46, 6041-6049. [CrossRef]

6. Edenhofer, O.; Pichs-Madruga, R.; Sokona, Y.; Farahani, E.; Kadner, S.; Seyboth, K.; Adler, A.; Baum, I.; Brunner, S.; Eickemeier, P.; et al. Climate Change 2014: Mitigation of Climate Change; Contribution of Working Group III to the Fifth Assessment Report of the Intergovernmental Panel on Climate Change; Cambridge University Press: Cambridge, UK; New York, NY, USA, 2014.

7. Rodrigues, D.T.; Gonçalves, W.A.; Spyrides, M.H.C.; Santos e Silva, C.M.; de Souza, D.O. Spatial distribution of the level of return of extreme precipitation events in Northeast Brazil. Int. J. Climatol. 2020, 40, 5098-5113. [CrossRef]

8. Neves, D.J.D.; Alcântara, C.R.; Souza, E.P.D. Estudo de Caso de um Distúrbio Ondulatório de Leste sobre o Estado do Rio Grande do Norte-Brasil. Rev. Bras. Meteorol. 2016, 31, 490-505. [CrossRef]

9. Caetano, D.D.A. Análise Sinótica de Um Caso de Distúrbio Ondulatório de Leste Sobre a Cidade de Natal-RN. Bachelor's Thesis, Universidade Federal do Rio Grande do Norte, Natal, Brazil, 2017. Available online: http://monografias.ufrn.br/handle/123456 789/6113 (accessed on 11 February 2017).

10. Natal. Zoneamento Ambiental de Natal, Secretaria Municipal de Meio Ambiente e Urbanismo. 2008. Available online: https: / / www2.natal.rn.gov.br/semurb / paginas / ctd-594.html (accessed on 20 December 2020).

11. Alves, E.P.Q.; Pessoa, Z.S. Vulnerabilidade, Riscos e Desastres Socioambientais: O Caso do Bairro de Mãe Luiza-Natal/RN; Regimes Urbanos e Governança Metropolitana/Encontro Nacional de Rede Observatório das Metrópoles: Natal, Brazil, 2017.

12. Jansen, G.R.; Vieira, R. Evolução da paisagem: Situações de risco a escorregamento no município de Blumenau, SC. Rev. Estud. Ambient. 2012, 14, 58-76. [CrossRef]

13. Dias, F.P.; Herrmann, M.L.P. Susceptibilidade a Deslizamentos: Estudo de Caso no Bairro Saco Grande, Florianópolis-SC. Caminhos Geogr. 2002, 3, 57-73. Available online: http://www.seer.ufu.br/index.php/caminhosdegeografia/article/view/15295 (accessed on 27 January 2021).

14. Pinto, R.C.; Passos, E.; Caneparo, S.C. Considerações a respeito dos condicionantes utilizados em pesquisas envolvendo movimentos de massa. Geoingá Rev. Programa Pós-Grad. Geogr. 2013, 5, 102-124. [CrossRef]

15. Instituto Brasileiro de Geografia e Estatística (IBGE). Censo Demográfico 2010; Instituto Brasileiro de Geografia e Estatística (IBGE): Rio de Janeiro, Brazil, 2010.

16. Riehl, H. Waves in the Easterlies and the Polar Front in the Tropics; University of Chicago Press: Chicago, IL, USA, 1945; 79p.

17. Coutinho, E.D.C.; Fisch, G. Distúrbios ondulatórios de leste (DOLs) na região do Centro de Lançamento de Alcântara-MA. Rev. Bras. Meteorol. 2007, 22, 193-203. [CrossRef]

18. Berry, F.A.; Bollay, E.; Beers, N.R. Handbook of Meteorology; McGraw-Hill Book: New York, NY, USA, 1945; 1068p.

19. Rao, V.B.; Cavalcanti, I.F.; Hada, K. Annual variation of rainfall over Brazil and water vapor characteristics over South America. J. Geophys. Res. Atmos. 1996, 101, 26539-26551. [CrossRef] 
20. Lima, K.C.; Satyamurty, P.; Fernández, J.P.R. Large-scale atmospheric conditions associated with heavy rainfall episodes in Southeast Brazil. Theor. Appl. Climatol. 2010, 101, 121-135. [CrossRef]

21. Satyamurty, P.; Costa, C.P.W.; Manzi, A.O. Moisture source for the Amazon Basin: A study of contrasting years. Theor. Appl. Climatol. 2013, 111, 195-209. [CrossRef]

22. Coutinho, M.D.L.; Lima, K.C.; Santos, C.M.S. Moisture transport to weather present, past and future of South America. Rev. Bras. Geogr. Física 2013, 6, 945-958. [CrossRef]

23. Coutinho, M.D.L.; Lima, K.C.; Santos e Silva, C.M. Regional climate simulations of the changes in the components of the moisture budget over South America. Int. J. Climatol. 2016, 36, 1170-1183. [CrossRef]

24. Lorenz, E.N. Energy and numerical weather prediction. Tellus 1960, 12, 364-373. [CrossRef]

25. Holton, J.R. An Introduction to Dynamic Meteorology, 4th ed.; Academic Press: Cambridge, MA, USA, 1992; 535p.

26. Alves, J.E.D.C.A. Variações de Energia na Atmosfera em Um Caso de Precipitação Intensa no Município de Maceió/AL. Bachelor's Thesis, Universidade Federal do Rio Grande do Norte, Natal, Brazil, 2017. Available online: http://monografias.ufrn.br/handle/ $123456789 / 5457$ (accessed on 28 January 2021).

27. Lima, C.C.; Amaro, V.E.; Araújo, P.V.N.; Santos, A.L.S. Identificação e Avaliação de Zonas de Alagamentos Urbanos, com o Suporte de Geotecnologias, na Cidade de Natal, Nordeste do Brasil. Anu. Inst. Geociênc. 2019, 42, 378-394. [CrossRef]

28. Busman, D.V.; Amaro, V.E.; Souza-Filho, P.W.M. Análise estatística multivariada de métodos de vulnerabilidade física em zonas costeiras tropicais. Rev. Bras. Geomorfol. 2016, 17, 500-516. [CrossRef]

29. Saaty, T.L. Decision making with the analytic hierarchy process. Int. J. Serv. Sci. 2008, 1, 83-98. [CrossRef]

30. Lima, P.H.G.; de Almeida, L.Q.; Belchior, A.C.C.; Macedo, Y.M. Desastre socioambiental e ordenamento territorial no bairro Mãe Luíza, Natal-Rio Grande do Norte (RN), Brasil. Territorium 2020, 27, 37-49. [CrossRef]

31. Ferreira, R.R.; Correa, M.J.; Lima, K.C.; Coutinho, M.D.L. Estudo de caso de contribuição do fluxo de umidade em evento de precipitação intensa ocorrida no leste do Nordeste do Brasil em maio de 2017. Rev. Bras. Geogr. Física 2019, 12, 1844-1852. [CrossRef]

32. Correa, M.J.; Lima, K.C.; Coutinho, M.D.L. Contribuição dos fluxos de umidade em evento de precipitação intensa ocorrido no leste do Nordeste do Brasil em maio de 2017: Um estudo de caso. Rev. Bras. Geogr. Física 2019, 12, 1703-1712. [CrossRef]

33. Oliveira, D.H.M.C.; Lima, K.C. What is the return period of intense rainfall events in the capital cities of the northeast region of Brazil? Atmos. Sci. Lett. 2019, 20, e934. [CrossRef]

34. Rodrigues, D.T.; Gonçalves, W.A.; Spyrides, M.H.C.; Andrade, L.D.M.B.; de Souza, D.O.; de Araujo, P.A.A.; da Silva, C.M.S.; de Silva, C.M.S. Probability of occurrence of extreme precipitation events and natural disasters in the city of Natal, Brazil. Urban Clim. 2021, 35, 100753. [CrossRef]

35. Oliveira, P.T.D.; Silva, C.M.S.; Lima, K.C. Climatology and trend analysis of extreme precipitation in subregions of Northeast Brazil. Theor. Appl. Climatol. 2017, 130, 77-90. [CrossRef]

36. Rodrigues, D.T.; Gonçalves, W.A.; Spyrides, M.H.C.; Silva, C.M.S. Spatial and temporal assessment of the extreme and daily precipitation of the Tropical Rainfall Measuring Mission satellite in Northeast Brazil. Int. J. Remote Sens. 2020, 41, 549-572. [CrossRef]

37. Torres, R.R.; Ferreira, N.J. Case studies of easterly wave disturbances over Northeast Brazil using the Eta Model. Weather Forecast. 2011, 26, 225-235. [CrossRef]

38. Palharini, R.S.A.; Vila, D.A. Climatological behavior of precipitating clouds in the northeast region of Brazil. Adv. Meteorol. 2017, 2017, 5916150. [CrossRef]

39. Gomes, H.B.; Ambrizzi, T.; da Silva, B.F.P.; Hodges, K.; Dias, P.L.S.; Herdies, D.L.; Silva, M.C.L.; Gomes, H.B. Climatology of easterly wave disturbances over the tropical South Atlantic. Clim. Dyn. 2019, 53, 1393-1411. [CrossRef]

40. Da Silva, B.F.P.; Fedorova, N.; Levit, V.; Peresetsky, A.; Brito, B.M.D. Sistemas sinóticos associados às precipitações intensas no Estado de Alagoas. Rev. Bras. Meteorol. 2011, 26, 323-338. [CrossRef]

41. Natal. Plano Municipal de Saneamento Básico do Município de Natal/RN: Situação dos Serviços de Drenagem e Manejo de Águas Pluviais Urbanas; Natal Start: Natal, Brazil, 2014; 142p.

42. Lima, P.H.G.; Almeida, L.Q. Desastre socioambiental e ordenamento territorial no bairro Mãe Luiza, Natal-RN, Brasil. Rev. Geociênc. Nordeste 2018, 4, 81-98. Available online: https:/ / periodicos.ufrn.br/revistadoregne/article/view/15245 (accessed on 20 December 2020).

43. Maciel, A.B.C.C.; Macedo, Y.M.; Almeida, L.Q. Índice de vulnerabilidade socioambiental (ivsa): Estudo de caso do bairro de mãe Luíza-Natal/rn, Brasil em escala de detalhe. Geologia 2015, 28. Available online: http:/ / www.periodicos.ufc.br/index.php/ geologia/article/view/2571 (accessed on 20 December 2020).

44. Macedo, Y.M.; Almeida, L.Q.; Maciel, A.B.C.; Troleis, A.L. Vulnerabilidade socioambiental em escala de detalhe: O caso de mãe Luiza, Natal, rn, Brasil. GEOSABERES Rev. Estud. Geoeduc. 2015, 6, 145-157. Available online: https://www.redalyc.org/pdf/55 28/552856410013.pdf (accessed on 20 December 2020). 